\title{
Article \\ Spectroscopic and Spectrometric Applications for the Identification of Bioactive Compounds from Vegetal Extracts
}

\author{
José Daniel Lozada-Ramírez $^{1}{ }^{(D}$, Ana E. Ortega-Regules ${ }^{2}$, Luis Ricardo Hernández ${ }^{1}$ (D) \\ and Cecilia Anaya de Parrodi 1,* \\ 1 Departamento de Ciencias Químico Biológicas, Universidad de las Américas Puebla, \\ 72810 San Andrés Cholula, Mexico; jose.lozada@udlap.mx (J.D.L.-R.); luisr.hernandez@udlap.mx (L.R.H.) \\ 2 Departamento de Ciencias de la Salud, Universidad de las Américas Puebla, \\ 72810 San Andrés Cholula, Mexico; ana.ortega@udlap.mx \\ * Correspondence: cecilia.anaya@udlap.mx; Tel.: +52-222-2292005
}

check for updates

Citation: Lozada-Ramírez, J.D.; Ortega-Regules, A.E.; Hernández, L.R.; Anaya de Parrodi, C.

Spectroscopic and Spectrometric Applications for the Identification of Bioactive Compounds from Vegetal Extracts. Appl. Sci. 2021, 11, 3039. https://doi.org/10.3390/app11073039

Academic Editors: Federico Marini and Alessandra Biancolillo

Received: 18 December 2020

Accepted: 3 March 2021

Published: 29 March 2021

Publisher's Note: MDPI stays neutral with regard to jurisdictional claims in published maps and institutional affiliations.

Copyright: (C) 2021 by the authors. Licensee MDPI, Basel, Switzerland. This article is an open access article distributed under the terms and conditions of the Creative Commons Attribution (CC BY) license (https:/ / creativecommons.org/licenses/by/ $4.0 /)$.
Featured Application: Separation and quantification by chromatographic methods, combined with spectroscopic and spectrometric techniques, are relevant in the characterization and quantification of natural polyphenols and anthocyanins. These compounds have nutraceutical properties, which are very important for the food industry.

\begin{abstract}
The use of spectroscopic and spectrometric techniques to isolate, quantify, and characterize bioactive compounds from edible plants has become a common and mandatory activity in food chemistry. As technology advances, diverse methodologies are being applied more frequently, which are coupled most of the time to give the best diagnosis and information of a metabolite of interest. In this paper, we state the different approaches that have been performed by our research group to isolate, identify, and apply the different bioactive organic compounds obtained from some vegetal extracts. Through this review, we show the importance of the use of those analytical tools to evaluate the possible impact of some plants we included on diet for improving human health.
\end{abstract}

Keywords: spectroscopy; spectrometry; vegetables; bioactive molecules; antioxidants; identification; characterization

\section{Introduction}

The need to know the food quality has led researchers to use various analytical methods to determine some principal food constituents. The most commonly used techniques are classified as follows: chromatography, sensors, spectroscopy, spectrometry, and combinations of these techniques [1].

Mass spectrometry is widely used to analyze foods and beverages and is mainly coupled with gas chromatography to identify single compounds and seek contaminants or adulterations. Other techniques involving mass spectrometry (MS) are proton transfer reaction (PTR)-MS, inductively coupled plasma (ICP)-MS, and gas chromatography (GC)MS or high-performance liquid chromatography (HPLC)-MS. The PTR-MS technique is a quantitative method for determining volatile organic compounds [2] with a reduced fragmentation, which makes this technique easy to interpret. Tandem-MS $\left(\mathrm{MS}^{\mathrm{n}}\right)$, which is useful for identifying compounds, analyzes fragments of fragments $[3,4]$.

Ultraviolet-visible spectroscopy (UV-vis) is a tool for determining the polyphenol content of foods and beverages and study the antioxidant properties and changes related to storage [5].

Infrared spectroscopy (IR), along with other techniques, helps obtain conclusive analysis results. It is a rapid and inexpensive method applied for food product analysis. Of the three regions in which the IR spectrum is divided, the middle (400-4000 $\left.\mathrm{cm}^{-1}\right)$ and 
near regions (4000-14,000 $\left.\mathrm{cm}^{-1}\right)$, abbreviated as MIR and NIR, respectively, are particularly useful for food analysis.

Over the past two decades, the view on nuclear magnetic resonance spectroscopy has changed from being a purely structural elucidation technique to being an analytical technique with particular usefulness in the field of food [6].

Plants have a highly developed secondary metabolism that produces many nonvital, but essential compounds for adapting to the surrounding environment where they live. These compounds are called secondary metabolites or natural products and have various biological activities, including antibiotic, antifungal, antiviral, herbicide, insecticide, anticancer, antioxidant, and antidiabetic activities $[7,8]$. Chemically, these substances belong to different types of compounds, such as terpenes, alkaloids, polyketides, flavonoids, and iridoids, among others. Along with other pigments, anthocyanins belonging to the flavonoid type are responsible for imparting color to the plants or products derived from them. In addition, these compounds also possess pharmacological properties (e.g., reducing capillary fragility and permeability and antioxidant, anti-inflammatory, and antiedema activity) [9].

This work presents some vegetal product analyses using chromatographic and spectroscopic and spectrometric techniques to measure, separate, and identify bioactive compounds from their extracts, centering on some works developed by our research group.

\section{Discussion}

According to Bernhoft [10], the main bioactive compounds found in plants can be classified in (a) glycosides, (b) flavonoids and proanthocyanidins, (c) tannins, (d) monoand sesqui-terpenoids, and phenylpropanoids, (e) diterpenoids, (f) resins, (g) lignans, (h) alkaloids, (i) furocoumarins and naphtodianthrones, and (j) proteins and peptides.

\section{Glycosides}

The glycosides comprise a group of diverse compounds attached to mono- or oligosaccharides or uronic acid (Figure 1). These bioactive compounds have been attributed to some beneficial activities in human health, such as anticancer, antimicrobial, antiviral, cardioprotective effects, amongst others. This group is formed by specific secondary metabolites, widely distributed in plants, with the most important being (i) cardiac glycosides, (ii) cyanogenic glycosides, (iii) glucosinolates, (iv) saponins, and (v) anthraquinone glycosides [10].

The identification of glycosides has been a common task due to the importance of these compounds. For this, spectroscopic and spectrometric methods have been applied to isolate, purify, identify, and quantify their presence in samples from diverse vegetal products. For example, the use of IR and UV-vis, nuclear magnetic resonance (NMR), MS, HPLC-UV-vis, and ultra-high-performance liquid chromatography (UPLC)-UV-vis methods have been applied for those purposes in recent years. Table 1 shows some examples of bioactive compounds, including a cardenolide glycoside, isolated from plant sources, their bioactive properties, and the methodologies used for their measuring.

\section{Flavonoids and proanthocyanidins}

Flavonoids comprise a group of bioactive substances with the presence of phenolic rings. These compounds contain molecules that are recognized for their beneficial effects on human health, associated with their high antioxidant anti-inflammatory, anticarcinogenic, antiviral, antimicrobial activities, amongst others. Several plants exhibit the presence of these bioactive molecules in different structures of their organisms-for example, in fruits, flowers, stems, grains, and barks. Flavonoids group commercially important compounds such as (i) flavones, (ii) isoflavones, (iii) flavonols, (iv) flavanols, (v) flavanones, (vi) flavanonols, (vii) proanthocyanidins, (viii) chalcones, and (ix) anthocyanins (Figure 2).

Due to the diverse biological activities of flavonoids and proanthocyanidins, they have received much attention. Nevertheless, their stability is a challenge for their application as nutraceuticals, cosmetics, pigments, and drugs. Table 1 shows examples of a flavonoid and 
a proanthocyanidin that have been studied very recently as well as the analytical methods used to isolate and characterize these molecules.

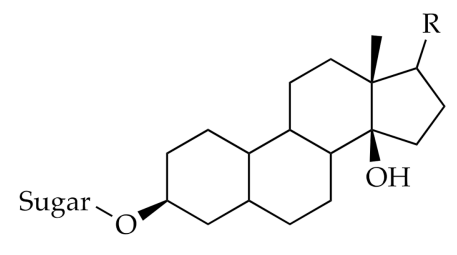

Cardiac glycoside

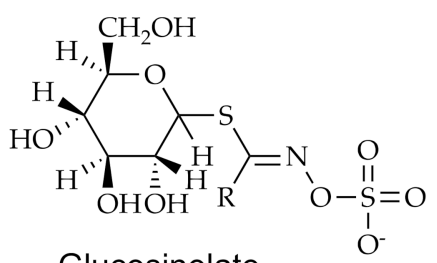

Glucosinolate

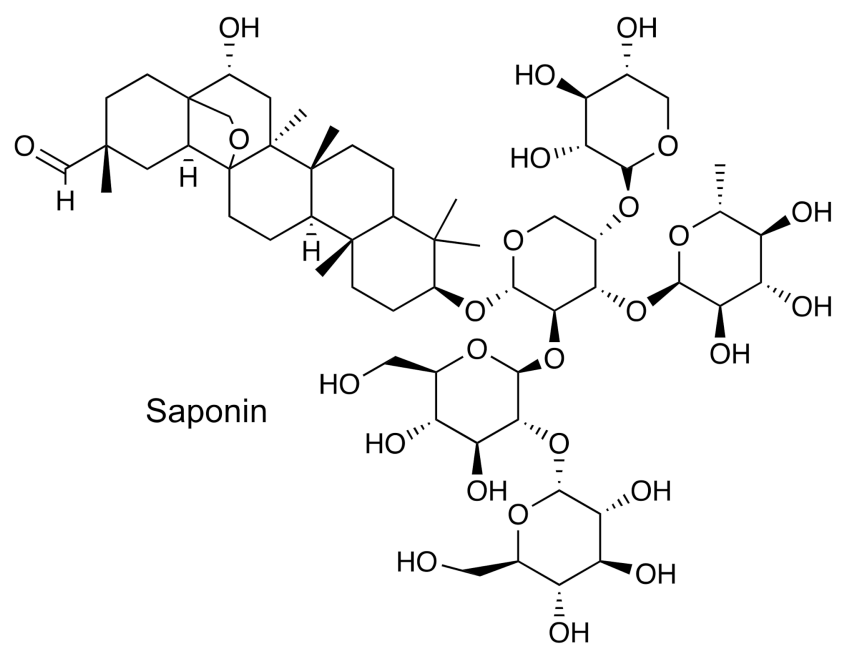

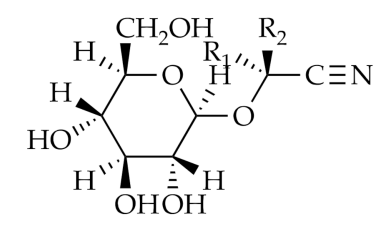

Cyanogenic glycoside<smiles>[R6]c1cc(O)c2c(c1)C(=O)c1cc([R6])cc(O)c1C2=O</smiles>

Anthraquinone glycoside

Figure 1. The chemical structures for some glycosides.

Table 1. Some bioactive compounds from plants, their properties, and the methodologies used for their identification and quantification.

\begin{tabular}{|c|c|c|c|c|c|}
\hline Group & Example & Source & Activity & References & Methods \\
\hline Glycosides & Cardenolide & Nerium oleander & $\begin{array}{l}\text { Anti-inflammatory, } \\
\text { anticancer }\end{array}$ & [11] & $\begin{array}{l}\text { IR, UV-vis; } \\
\text { HPLC-UV-vis } \\
\text { NMR }\end{array}$ \\
\hline Flavonoids & Silibinin & Silybum marianum & $\begin{array}{l}\text { Anti-inflammatory, } \\
\text { anticancer }\end{array}$ & [12-15] & $\begin{array}{l}\text { IR; HPLC-UV-vis; } \\
\text { LC-MS }\end{array}$ \\
\hline Proanthocyanidins & A- and B-type & $\begin{array}{l}\text { Cranberry, bilberry, } \\
\text { curry, cinnamon, } \\
\text { tea }\end{array}$ & $\begin{array}{l}\text { Anti-inflammatory, } \\
\text { anticancer, } \\
\text { anti-microbial, } \\
\text { hypolipidemic }\end{array}$ & {$[16,17]$} & $\begin{array}{l}\text { IR; NMR; FT-ICR- } \\
\text { ESI-MS-MS; } \\
\text { UPLC-IM-HR-MS }\end{array}$ \\
\hline Stilbenoids & Resveratrol & $\begin{array}{c}\text { Grape, apple, } \\
\text { berries, pistachios, } \\
\text { peanuts }\end{array}$ & $\begin{array}{l}\text { Anti-inflammatory, } \\
\text { anticancer; } \\
\text { anti-microbial, } \\
\text { anti-diabetic }\end{array}$ & {$[18,19]$} & $\begin{array}{l}\text { HPLC-UV-vis; } \\
\text { UPLC-MS-MS; } \\
\quad \text { NMR }\end{array}$ \\
\hline Tannins & Ellagitannins & $\begin{array}{l}\text { Sorghum, apple, } \\
\text { grape }\end{array}$ & $\begin{array}{c}\text { Anti-inflammatory, } \\
\text { anticancer, antimicrobial, } \\
\text { antiviral }\end{array}$ & {$[20,21]$} & $\begin{array}{l}\text { HPLC-UV-vis; } \\
\text { NMR; HPLC } \\
\text { ESI-MS-MS }\end{array}$ \\
\hline
\end{tabular}


Table 1. Cont.

\begin{tabular}{|c|c|c|c|c|c|}
\hline Group & Example & Source & Activity & References & Methods \\
\hline Monoterpenoids & Limonene & Quercus ilex & $\begin{array}{c}\text { Anti-inflammatory, } \\
\text { anticancer }\end{array}$ & [22-24] & $\begin{array}{l}\text { FGC-PTR-MS; } \\
\text { NMR }\end{array}$ \\
\hline Sesquiterpenoids & Zerumbone & Zingiber zerumbet & $\begin{array}{c}\text { Anti-inflammatory, } \\
\text { anticancer, antimicrobial, } \\
\text { antipyretic }\end{array}$ & {$[25,26]$} & $\begin{array}{c}\text { GC-MS; IR, NMR; } \\
\text { ESI-MS }\end{array}$ \\
\hline Phenylpropanoids & Coumarins & Artemisa annua & $\begin{array}{l}\text { Anti-inflammatory, } \\
\text { anticancer, antimicrobial, } \\
\text { antiviral, antiparasitic }\end{array}$ & {$[27,28]$} & $\begin{array}{l}\text { HPLC-UV-vis; LC- } \\
\text { ESI-QTOF-MS-MS }\end{array}$ \\
\hline Diterpenoids & Columbin & Jateorhiza columba & Analgesic, antipyretic & {$[29,30]$} & $\begin{array}{l}\text { NMR; LC-MS; } \\
\text { UPLC-HR-MS }\end{array}$ \\
\hline $\begin{array}{l}\text { Tetraterpenoids } \\
\text { (Carotenoids) }\end{array}$ & $\begin{array}{c}\alpha \text { - and } \\
\beta \text {-carotene }\end{array}$ & $\begin{array}{c}\text { Carrot, cantaloupe, } \\
\text { tomato }\end{array}$ & $\begin{array}{c}\text { Antioxidant, } \\
\text { chemopreventive }\end{array}$ & {$[31,32]$} & $\begin{array}{c}\text { HPLC-UV-vis; } \\
\text { HPLC-ESI-MS-MS; } \\
\text { GC-MS }\end{array}$ \\
\hline Resins & $\begin{array}{l}\text { Stytonkinol A } \\
\text { and B }\end{array}$ & Styrax benzoin & $\begin{array}{l}\text { Antimicrobial, } \\
\text { antifungal }\end{array}$ & {$[33,34]$} & IR; UV-vis; NMR \\
\hline Lignans & Dibenzylbutane & Phyllanthus niruri & Antiviral, antioxidant & {$[35,36]$} & $\begin{array}{l}\text { HPLC-DAD-ESI- } \\
\text { QTOF-MS; } \\
\text { NMR }\end{array}$ \\
\hline Alkaloids & Triangularine & Asteraceae family & $\begin{array}{l}\text { Anti-inflammatory, } \\
\text { antioxidant, } \\
\text { antimicrobial, anesthetic }\end{array}$ & {$[37,38]$} & $\begin{array}{l}\text { HPLC-UV-vis: } \\
\text { LC-MS-MS; NMR }\end{array}$ \\
\hline Furocoumarines & Bergamottin & Grapefruit, orange & Anticancer & {$[39,40]$} & $\begin{array}{c}\text { UV-vis; } \\
\text { UPLC-MS-MS }\end{array}$ \\
\hline Naphthodianthrones & Hypericin & $\begin{array}{l}\text { Hypericum } \\
\text { triquetrifolium }\end{array}$ & $\begin{array}{c}\text { Anti-inflammatory, } \\
\text { anticancer, antimicrobial, } \\
\text { antiviral, antidepressant }\end{array}$ & {$[41,42]$} & UPLC-ESI-MS-MS \\
\hline Peptides & Sesquin & Vigna sesquipedalis & Anticancer & {$[43,44]$} & $\begin{array}{c}\text { IR; } \\
\text { MALDESI-MS-MS }\end{array}$ \\
\hline Proteins & Lectins & Ricinus communis & Antimicrobial & {$[45,46]$} & LC-QTOF-MS-MS \\
\hline
\end{tabular}

Abbreviations: Diode array detection (DAD); Electrospray ionization (ESI), Flash gas chromatography (FGC), High-resolution (HR), Matrix-assisted laser desorption electrospray ionization (MALDESI), Proton transfer reaction (PTR), Quadrupole time-of-flight (QTOF), and Ultra-high-performance liquid chromatography (UPLC).<smiles>O=c1cc(-c2ccccc2)oc2ccccc12</smiles>

Flavonoid<smiles>Oc1cc(O)c2c(c1)OC(c1ccc(O)c(O)c1)C(OC1Oc3cc(O)cc(O)c3C(O)C1O)(c1ccc(O)c(O)c1)C2</smiles>

Proanthocyanidin

Figure 2. The general structures for flavonoids and proanthocyanidins.

During the last decade, our research group has been working in the extraction, purification, and characterization of anthocyanins (Figure 3), which are flavonoids that have demonstrated ample possibilities for their application as natural pigments, nontoxic food additives, nutraceuticals, and antioxidants. For the above, a detailed description of this research, and references from others related, are described. 
Anthocyanin identification and separation from foods are widely performed activities. Individual components must be separated from foods and beverages to evaluate their biological activities. For the specific case of anthocyanins, using HPLC-UV-vis has become the most important approach for identifying and separating these compounds [47,48].<smiles></smiles>

$\begin{array}{lll}\text { Anthocyanin } & \mathbf{R}_{\mathbf{1}} & \mathbf{R}_{\mathbf{2}} \\ \text { Cyanidin } & -\mathbf{O H} & -\mathbf{H} \\ \text { Delphinidin } & -\mathbf{O H} & -\mathbf{O H} \\ \text { Malvidin } & -\mathbf{O C H} \mathbf{H}_{3} & -\mathrm{OCH}_{3} \\ \text { Pelargonidin } & -\mathbf{H} & -\mathbf{H} \\ \text { Peonidin } & -\mathbf{O C H} & -\mathbf{H} \\ \text { Petunidin } & -\mathbf{O H} & -\mathbf{O C H}_{3}\end{array}$

Figure 3. The general structure of anthocyanins and most representative molecules with their substituents. Adapted from [49].

The ultraviolet absorption spectra of these phenolic compounds can be taken advantage of to follow and separate different anthocyanins from foods and beverages using the UV-vis interval (200-750 nm). Chromatographic column techniques are useful in separating anthocyanins from extracts and different anthocyanins based on their retentio properties.

A study performed by our research group on the extracts of roselle calyxes (Hibiscus sabdariffa) afforded a chromatogram with 25 different compounds having maximum absorbances in the range of $270-520 \mathrm{~nm}$. From these peaks, we identified 23 compounds employing $\mathrm{MS}^{\mathrm{n}}$. The most abundant compounds in the extract comprise chlorogenic acid, 5-O-caffeoylquinic acid, 4-O-caffeoylquinic acid, and the anthocyanins delphinidin3-O-sambubioside (D3S), delphinidin-3-O-glucoside (D3G), cyanidin-3-O-sambubioside (C3S), Cyanidin-3-O-glucoside (C3G), quercetin-3-O-sambubioside (Q3S), quercetin-3-Oglucoside (Q3G), quercetin-3-O-rutinoside (Q3R), myricetin-3-O-sambubioside (MY3S), quercetin-3-O-rutinosil-7-O-xyloside (Q3R7X), kaempferol-3-O-rutinoside (K3R), quercetin3-O-(2'-coumaroyl)-sambubioside (Q3(2C)S), quercetin-3-O-(2'-coumaroyl)-rutinoside $(\mathrm{Q} 3(2 \mathrm{C}) \mathrm{R})$, and quercetin (unpublished results). In the same way, Mourtzinos et al. [50] obtained the phenolic compound profile by liquid chromatography (LC)-MS, including chlorogenic acid, quercetin, myricetin, caffeic acid, syringic acid, kaemferol, gallic acid, sinapic acid, ursolic acid, ferulic acid, p-coumaric acid, protocatechuic acid, and epicatechin. Differences exist in the composition and abundance of phenolics caused by the differences in the sample origin [51,52].

Spectrophotometric measures with multidiode array detectors must be performed individually or in association with HPLC equipment. This technology allows the analysis of a sample on a broad range of UV-vis wavelengths. Using combined techniques for the separation and identification of phenolic compounds determines the association of the active properties observed on a natural product to a specific substance present on food.

The phenolic compound characterization is an affordable process applying specific techniques. For example, characterization of anthocyanins from roselle calyxes (Hibiscus sabdariffa), blue maize (Zea mays), coffee fruit (Coffea arabica), blueberry (Vaccinium ashei), 
and from beverages prepared from these products can be carried out using spectroscopic and spectrometric techniques.

The characterization of extracts from vegetal products with anthocyanins implies the measurement of the total phenolic compounds, total monomeric anthocyanins, antioxidant activity, and color assessment. The Folin-Ciocalteu method is used to determine the total phenolic compounds. It quantifies the antioxidant or reductive capacity of the phenolic compounds present in a sample. The method exploits a colorimetric reaction evaluated by UV-vis spectrophotometry due to the formation of a blue chromophore of the phosphomolybdenum-tungstic plus phenolic compound-complex at $765 \mathrm{~nm}[53,54]$. The most common standard used to generate a calibration curve is gallic acid; thus, the phenolic content results are usually expressed as mg gallic acid equivalents (GAE). In our group, we quantified the total phenolic compounds from blueberry (Vaccinium ashei) spray-dried extracts with the Folin-Ciocalteu method. The obtained results represent the precision of the approach - in other words, high linearity, low limit of detection, high limit of quantification, high reproducibility, and excellent accuracy. First, we obtained microcapsules that can retain anthocyanins. A value of $24.92 \mu \mathrm{mol} \mathrm{GAE} / \mathrm{g}$ wet weight of blueberry was determined from the fruit slurry before microcapsule preparation. Consequently, we achieved a retention of more than $95 \%$ in one of the powders prepared by spray drying. The application of spectrophotometric techniques undeniably enabled the initial quantification following the evolution of the anthocyanin quantities during storage of the food product [55].

The total monomeric anthocyanins can be determined through the $\mathrm{pH}$ differential method, which is a simple spectroscopic assay involving anthocyanin transformation when a change in $\mathrm{pH}$ is applied. This is used as the standard methodology approved by the Methods Committee on Commodity Foods and Commodity Products as First Action of the Association of Official Agricultural Chemists for anthocyanin quantification [56]. The method is based on a sample of free anthocyanins presenting a particular hue (e.g., red, purple, and blue) at $\mathrm{pH} 1.0$ and turned to colorless at $\mathrm{pH} 4.5$; thus, the difference in absorbance can be measured. Beginning from an acidic $\mathrm{pH}$ of 1 , individual (nonpolymerized) anthocyanins present colors on the interval of orange to purple due to the presence of its predominant form of the flavylium cation. Turning the $\mathrm{pH}$ to neutral (7.0) represents a color change to blue caused by the deprotonation of the flavylium cation to form the quinoidal base of the anthocyanin. On the contrary, the change of $\mathrm{pH}$ from 1.0 to less acidic $\mathrm{pH}$ of 4.5 implies the change of the flavylium cation form to a carbinol pseudo base as a cause of water introduction. This structure reaches equilibrium with a colorless chalcone structure.

The quality of fresh and processed foods containing anthocyanins can be determined by spectrophotometrically following $(520 \mathrm{~nm})$ the anthocyanin evolution during the shelf life of fruit or vegetal juice, pulp from fruits, flowers, seeds, grains, wine, and pigments extracted from vegetables. The expression of the results is related to the main anthocyanin present in the product. For example, the major monomeric anthocyanin in wine is malvidin-3-O-glucoside (M3G). Using the molar absorptivity coefficient $(\varepsilon)$ of the evaluated anthocyanin is required. Thus, the results are commonly expressed as $\mathrm{mg}$ of M3G/g or mL sample [57].

Another wine illustration implies the spectrophotometric detection and quantification of polymeric anthocyanins. Therefore, the polymeric anthocyanin concentration must be established by mixing a sample of the product with $5 \% \mathrm{SO}_{2}$, then measuring the mixture absorbance at $520 \mathrm{~nm}$ [58]. The polymeric anthocyanin quantification through this methodology allowed the comparison between the content of polymeric anthocyanins in control wines and wines enzymatically treated with pectinolytic enzymes to improve the release of the bioactive compounds (an increase from 23\% to 33\%) responsible for the color and beneficial effects on human health [59].

Measuring the color of food products can be spectrophotometrically performed by applying the methodology proposed by the International Commission on Illumination, called the CIEL $a^{*} b^{*}$ system. The measures require the use of colorimeter equipment usually 
with color sensor wavelengths of 400 to $720 \mathrm{~nm}$. The color of food products represents a major quality characteristic; thus, it must be assessed by measuring the hue parameters. The term $L^{*}$ represents the clarity or brightness of a sample; hence, $L^{*}=100$ represents white, and $L^{*}=0$ represents black. In contrast, the $a^{*}$ and $b^{*}$ parameters have positive and negative values, with values $\mathrm{a}^{*+}$ denoting a tendency represented by the red color and $\mathrm{a}^{*}-$ by green. Additionally, $\mathrm{b}^{*+}$ is yellow, and $\mathrm{b}^{*}-$ is blue. In the laboratory, it is also common to determine the color intensity of a sample as the sum of the absorbances of the sample at 620 (blue color), 520 (red color), and $420 \mathrm{~nm}$ (yellow color). Another parameter for determining this is the tone or tint of the sample by calculating the ratio Abs $420 / \mathrm{Abs}$ 520 [59].

Studies on color have led to the understanding of the importance of the compounds responsible for providing this characteristic in wines and the importance of their localization within the cell. Spectrophotometrically evaluating the extractability of phenolic compounds, tannins, and anthocyanins from inside the cell wall of a grape cell, where they are protected from degradation, is easy [60]. Additional studies have demonstrated the adherence of anthocyanins to the polysaccharides and proteins of the cell wall, causing a diminishing in the compound content [61]. For this, it is important to determine the chromatic characteristics of wine through the spectrophotometric measure of its color intensity. A member of this research group has been working on analyzing these chromatic properties in wines from Spain by evaluating the effect of enzymatic treatments on anthocyanin extraction through a comparison of the color intensities of treated wine with untreated wine. The results evidenced an increase in the color intensities of treated wine of more than $20 \%$ with a total phenolic content of $25 \%$ and a total monomeric anthocyanin content of $23 \%$, which are higher than those obtained for untreated wine [62]. Additionally, the usage of a combination of pectolytic enzymes was demonstrated as an alternative for increasing the color intensity in wines by more than $18 \%$ [59].

The antioxidant activity is a key parameter for determining the bioactive properties of foods. The antioxidant property of a substance is defined as its capacity to prevent or diminish the oxidation caused by the electron transfer from a donor to an acceptor. The oxidative processes in human beings cause the proliferation of unstable chemical species. These processes alter the normal metabolism and are associated with multiple disorders and illnesses, such as cancer, diabetes, metabolic syndrome, aging, Parkinson's disease, Alzheimer's disease, heart disease, and stroke, among others [63-66]. Several natural antioxidants are well known and alphabetically classified as antioxidants C (carotenoids), E (enzymes), G (glutathione), L (lipids), and P (phenolics) [67]. Many spectrophotometric techniques are useful in antioxidant characterization. At present, the most frequently applied techniques are the 2,2-diphenyl-1-picrylhydrazyl (DPPH) [68] and the 2,2' azino-bis-(3-ethylbenzothiazoline-6-sulfonic acid (ABTS) radical scavenging assays [69]. Other related methodologies have been reported in the literature [70,71], including ferricreducing antioxidant power (FRAP) [72], oxygen radical absorption capacity (ORAC) [73], Trolox equivalent antioxidant capacity (TEAC) [74], N,N-dimethyl-p-phenylenediamine (DMPD) [75], and $\mathrm{Cu}(\mathrm{II})$ reduction capacity assay (CUPRAC) [76].

DPPH testing is an easy and fast method, which is especially important for lipophilic antioxidants [77]. The approach consists of preparing a methanol solution of DPPH to form the $\mathrm{DPPH}^{\bullet}$, a stable radical of purple color that can be spectrophotometrically measured at $515 \mathrm{~nm}$. This radical can accept one hydrogen from the antioxidant to form a yellow-colored DPPH2 that comes from the antioxidant substance, a reaction that causes a diminishing in the absorbance at $515 \mathrm{~nm}$. Meanwhile, the ABTS test uses the greencolored radical $\mathrm{ABTS}^{\bullet+}$ by $\mathrm{ABTS}$ oxidation with potassium persulfate. Similar to that observed for DPPH, ABTS ${ }^{\bullet+}$ stabilizes through the reduction provoked by the antioxidant compound. The result is a colorless solution that can be spectrophotometrically followed at $415 \mathrm{~nm}$ [69]. This methodology allows the evaluation of both hydrophilic and lipophilic substances. The results are expressed referring in comparison to the standard scavenger 
Trolox, a vitamin E analog that serves to construct a calibration curve. Trolox equivalents (TEs) indicate the antioxidant present for both assays [77].

Previous works have dealt with the evaluation of the antioxidant activity of several vegetal products and extracts obtained from them, which is the case of diverse berries [78], grapes [79], wines [80], kiwi [81], tea [82], ginger [83], carrot [84], quinoa [85], maize [86,87], ginkgo [88], and so on. In our laboratory, we have been working on several vegetables to evaluate their antioxidant properties for diverse purposes. This is the case of the evaluation of the antioxidant activity retention of spray-dried blueberry extracts [55]. In this work, we report the high antioxidant activity of blueberry extracts (116.2 TE/g soluble solid of the blueberry extract) following the abovementioned spectrophotometric ABTS assay [89]. The time evolution of the spray-dried extracts from the blueberry is also spectrophotometrically followed. These extracts reach values as high as 101.89-102.22 TE/g ss berry extracts, corresponding to antioxidant activity retentions of more than $87 \%$ in some of the prepared capsules. In addition, we reported on the evaluation of phenolic compounds to measure the antioxidant activity of the extracts from pigmented maize (Zea mays), roselle calyxes (Hibiscus sabdariffa), mamey (Pouteria sapota), coffee fruit (Coffea arabica), carrot (Daucus carota), and passion fruit (Passiflora edulis).

A study focused on the antioxidant activity of anthocyanins from Hibiscus sabdariffa L. [90] deals with the measuring of roselle petals' extracts cultivated in Taiwan. In this work, the antioxidant activity was measured through FRAP, ORAC, and total antioxidant status (TAS) assays. It is noteworthy that the extraction time was positively correlated with the antioxidant activity of the extracts. In this regard, the longer was the extraction the most antioxidant activity of the extracts was detected, no matter the methodology employed. Additionally, there was a linear relationship between all the assays probed in this work. As well, other authors have made evident the reducing capacity of the extracts of roselle attributed to the presence of anthocyanins, either using the ABTS, DPPH, or ORAC methodologies [91,92].

Related to the extraction of anthocyanins from roselle, Cissé et al. [93] established a mathematical model to predict the thermo-degradation kinetics of water-extracted anthocyanins. For this purpose, total monomeric anthocyanins were spectrophotometrically measured using the $\mathrm{pH}$ differential method $(510 \mathrm{~nm})$. In this way, it was possible to spectrophotometrically follow the degradation of anthocyanins to construct a mass transfer model.

For the pigmented maize, some studies have enabled the identification of anthocyanins present in this product. Lao and Giusti [94] obtained the HPLC profiles of the anthocyanins present in powders from purple maize cobs using a diode array detector (DAD). The results showed the presence of C3G as the major anthocyanin present in this pigmented grain, followed by cyanidin-3-malonylglucoside (C3MG), peonidin-3-O-glucoside (P3G), pelargonidin-3-(6"-malonyl-glucoside) (PG3(6MG)), pelargonidin-3-O-glucoside (PG3G), and peonidin 3-(6"malonyl-glucoside) (P3(6MG)). In this sense, we have been working on the extraction, quantification, and identification of anthocyanins from blue maize from central Mexico (unpublished data). Accordingly, the LC-MS generated from the extracts of two varieties of the blue maize revealed the existence of phenolic compounds with nutraceutical properties in different proportions; hence, the corn varieties can be assigned different beneficial properties because of the different constituent concentrations. The results illustrate the presence of the same anthocyanins, but in different proportions, which was expected considering the different soil compositions in which each crop has grown. It is especially important to determine the fingerprints for each cultivar from the separation, identification, and quantification of some compounds that serve as biomarkers. The combined use of these two powerful analytical tools (i.e., HPLC coupled with mass spectrometry) has enabled the identification of several bioactive compounds from different natural products and derived [95-98].

Related to the above, Žilić et al. [86] developed a study to isolate phenolic compounds and carotenoids from ten different colored maize genotypes from Mexico, USA, France, 
Serbia, and the Netherlands but grown in Serbia. In said study, the authors extracted the phenolic acids from the kernels using a mixture of acetone/methanol/water as extractant agent before alkaline hydrolysis with $\mathrm{NaOH}$. Those hydrolysates were extracted with nonpolar solvents and dried with $\mathrm{N}_{2}$. Then, they were dissolved in methanol for HPLC analysis on a C18 column, measuring at $280 \mathrm{~nm}$, and identifying the phenolic acid peaks by comparing retention times and absorption versus standards used to construct a calibration curve. On the other hand, anthocyanins from the samples were analyzed by UPLC (Ultra-high-performance liquid chromatography), through a C18 column, coupled with MS equipped with a heated electrospray interface. The anthocyanins of the mixtures extracted were identified and quantified by comparison with the standards of C3G, PG3G, cyanidin 3,5-diglucoside (C3,5DG), and pelargonidin-3,5-diglucoside (PG3,5DG). Additionally, the total phenolic content was determined following the procedure described by Folin-Ciocalteu, measuring the absorbance at $725 \mathrm{~nm}$ and expressing the content as GAE per kg of dry mass. Furthermore, the total flavonoid content was spectrophotometrically determined by measuring the absorbance of the extracts mixed with $\mathrm{NaNO}_{2}$ and reacted with $\mathrm{AlCl}_{3}$ to get flavanoid-aluminum complexes that were measured at $510 \mathrm{~nm}$, after being treated with $\mathrm{NaOH}$ and centrifuged, as described previously by Zhishen et al. [99]. The total antioxidant capacity was spectrophotometrically evaluated for the ten maize varieties through the use of two methodologies, ABTS and DPPH. For the ABTS methodology, a solution of ABTS with $\mathrm{K}_{2} \mathrm{~S}_{2} \mathrm{O}_{8}$ was prepared and left standing in the dark overnight to generate the radical $\mathrm{ABTS}^{\bullet+}$. The solution of the radical was adjusted to obtain an absorbance of $0.7 \pm 0.02$ at $734 \mathrm{~nm}$. For the case of DPPH, the solution was prepared in ethanol and adjusted to an absorbance of $1.0 \pm 0.05$ at $525 \mathrm{~nm}$. In both cases, the samples were added to $\mathrm{ABTS}^{\bullet+}$ or $\mathrm{DPPH}{ }^{\bullet}$ to measure the scavenging activity associated with the bioactive compounds extracted from maize. The obtained results were expressed as TE per $\mathrm{kg}$ of dry mass by comparison with this analog of vitamin $\mathrm{E}$.

Moreover, the application of anthocyanins in the food industry as pigments and because of its radical scavenging properties has led to the use of maize as a low-cost anthocyanin-rich vegetal source. Similarly, the higher the antioxidant activity is the higher phenolic content. The information above indicates that the use of spectrophotometric and spectrometric methods is required to evaluate the potential use of vegetables as a source of bioactive compounds acting positively in human health.

On the other hand, Urias-Lugo et al. [100] have reported the obtain of anthocyanins from Mexican pigmented maize due to their beneficial properties to health. The extraction of these biologically active compounds can be performed using solvents of different polarities-for example, water, ethanol, methanol, or acetone. In this work, the authors extracted these natural pigments by using acidified and nonacidified ethanol, following the reports previously published [101,102]. The analysis of phenolic acids was performed by HPLC equipped with a PDA using a reverse-phase column. Meanwhile, anthocyanins were analyzed by HPLC with a PDA and identified with HPLC coupled with time-of-flight (TOF)-MS. The analysis and quantification of the maize samples show the presence of C3G as the main anthocyanin. Nevertheless, the presence of two isomers of cyanidin di-succinyl-glucoside (CDSG) (I and II), three isomers of cyanidin-3-(6"malonyl-glucoside) (C3(6MG)) (I, II, and III), cyanidin-3-succinyl-glucoside (C3SG), PG3G, and pelargonidin-3(6"-malonyl-glucoside) (P3(6MG)). It is important to note the differences observed during the extraction process related to the use of acidified or nonacidified ethanol. These differences imply that some anthocyanins can be isolated and quantified when one extraction method is used but not with the other and vice versa. The above serves to highlight the importance of the method of extraction of biologically active compounds from vegetables. The authors concluded that the extraction with nonacidic ethanol was better than that with acid-ethanol because it contained more anthocyanins.

Another study was conducted to analyze the anthocyanins present in industrial preparations of pigmented maize [103]. This study aimed to analyze the anthocyanins composition of a commercial extract from purple maize, obtained from maceration with 
nonacidified ethanol. The analysis was developed using HPLC with a PDA detector (C18 column) coupled with a mass spectrometer with ESI interface. The findings show a different pattern of anthocyanins when compared to those reports from $[86,100]$. For example, C3G is the most abundant anthocyanin, but it is also revealed the presence of PG3G, P3G, C3(6MG), PG3(6MG), P3(6MG), cyanidin-3-(6"-ethyl malonyl-glucoside) (C3(6EMG)), pelargonidin 3-(6"-ethyl malonyl-glucoside) (PG3(6EMG)), and peonidin 3-(6"-ethyl malonyl-glucoside) (P3(6EMG)). From this list, the only PG3G were identified and quantified in the three studies, and PG3(6MG) in two of them [100,103]. Similar results to those obtained for de PascualTeresa et al. [103] were previously reported by Fossen et al. [104] from maize cultivated in England, with the presence of C3G, C3(6MG), cyanidin 3-(3",6"-dimalonylglucoside) (C3(3,6DMG)), P3G, P3(6MG), and peonidin 3-(dimalonylglucoside) (P3(DMG)). Interestingly, in this work is reported the presence of the same anthocyanins but in different proportions from samples of flowers of reed canary grass (Phalaris arundinacea), cultivated in Norway. For the above, it is evident that the use of spectrophotometric and spectrometric instrumentation permits the isolation and quantification of anthocyanins, allowing the identification of these bioactive compounds present in trace quantities. This can be applied in the fingerprinting of cultivars to determine their origin, particularly because, as reported elsewhere [105], the plant variety, geographical and climatic conditions, fertilization, soil, cultivation practices, and fruits' degrees of ripeness influence the presence of phenolic compound contents.

The quantification, separation, identification, and following of the extract stability by measuring the color and the antioxidant properties of anthocyanins are required activities that carried out with the support of spectroscopic and spectrometric applications. We have also been working on the modification of the previously known phenolic compounds to enhance their chemical stability through biomimetics. Using spectroscopic techniques to identify and quantify these novel compounds is transcendental. For example, anthocyanins can be chemically or enzymatically modified by acylation, glycosylation, and methylation $[106,107]$ to produce more stable compounds. These compounds could be differentiated from the original by identifying, measuring, and quantifying through HPLC-TOF-MS, UV-vis, and HPLC. This is the case of the chemical synthesis of six novel pyranoanthocyanins that were obtained by our research group from anthocyanins delphinidin-3-O-sambubioside (D3S) and C3S, which were extracted and purified from the extracts of roselle calyxes (Hibiscus sabdariffa L.), which is widely used to prepare alcoholic and nonalcoholic refreshing beverages and infusions. These anthocyanins reacted with 4-vinylphenol, acetone, and butanone to synthesize novel pigments, purified and characterized by UV-vis and HPLC, and identified by MS [108]. The original anthocyanins D3S and C3G showed maximum absorptions at 526 and $518 \mathrm{~nm}$, respectively. Nevertheless, the changes provoked by chemical modifications made to different spectra associated with the novel hydroxyphenyl-anthocyanins ( $\lambda_{\max } 503$ and $501 \mathrm{~nm}$, respectively) and to the synthesized methyl-pyranoanthocyanins ( $\lambda_{\max } 478$ and 354, 475 and 340, 480 and 353, and 478 and $338 \mathrm{~nm}$, respectively). The new pyranoanthocyanins have different spectroscopic properties compared with their original phenolics.

Additionally, the search for more stable antioxidant compounds was conducted to the anthocyanin stabilization through the construction of physical barriers, such as the micro- or nanoencapsulation of the phenolic compounds. Through the construction of these polymeric or nanostructure matrices, anthocyanins can endure for long-time periods, and the evolution of their preservation can be followed by spectroscopic means. Furthermore, the specific properties of these antioxidant compounds can be followed during the shelf life of the vegetal, food product, or from the extracts obtained from that vegetal. An example of this is our previous work on the stabilization of blueberry extracts as an anthocyanin source. Blueberry is an important local product consumed as jams and beverages. Unfortunately, blueberry and its anthocyanins responsible for providing color are very unstable. Blueberry extracts were spray-dried using as an encapsulating agent mesquite gum affording a powder to stabilize the color. We proceeded to the powder evaluation 
in terms of color and anthocyanin content over time of storage. The evaluation consisted of the spectroscopic quantification of the total phenolic content, total anthocyanins, antioxidant capacity, and color [55]. Consequently, the polymeric wall usage was found to be effective in avoiding the losses of phenolics, anthocyanins, and color under different storage conditions (light and temperature).

In terms of stability, our research group conducted another approach to look for the anthocyanin stabilization from coffee husks (Coffea arabica) by using ZnO nanoparticles. Herein, we were able to stabilize anthocyanins from the extracts obtained in this byproduct from the coffee industry. First, ZnO nanoparticles were successfully prepared following a previously described methodology [109] and used to stabilize the mentioned anthocyanins. Atomic absorption spectrometry was used to determine the mass of the anthocyanins coated by the $\mathrm{ZnO}$ nanoparticles by comparing the intensity of the signal obtained to a calibration curve previously prepared and convert the intensity into the zinc ion mass. The total mass of $\mathrm{ZnO}$ was stoichiometrically calculated and subtracted from the mass of the dried sample, obtaining the mass of the anthocyanins coating the nanoparticles (data unpublished).

Another spectroscopic technique frequently employed is infrared spectroscopy. It is useful to follow the amount and stability of anthocyanins over time. In previous work, anthocyanins from Hibiscus sabdariffa were used to dope titanium dioxide nanotubes and ensure more stability and capability for electrode regeneration. The complexation of these compounds can be measured and quantified using FTIR and UV-vis spectroscopy, determining changes in the absorbance profiles of the nanotubes with or without complexed anthocyanins [110]. The changes registered in the UV-vis spectra of the nanotubes against those complexed with anthocyanins can be followed using roselle extracts as the reference, which contain mainly D3S. Additionally, the infrared spectroscopy revealed the anthocyanin immobilization through the presence of characteristic peaks from 750 to $1700 \mathrm{~cm}^{-1}$. The presence of a band at $1700 \mathrm{~cm}^{-1}$ indicates the presence of organic acids, such as hibiscus acid. The peaks between 1630 and $1440 \mathrm{~cm}^{-1}$ were associated with the alkene and aromatic groups present in the polyphenols. The $\mathrm{C}-\mathrm{O}$ bonds present in the phenolic group and the sugar moiety of the anthocyanin skeleton appeared from 1040 to $1260 \mathrm{~cm}^{-1}$. Finally, the $\mathrm{C}-\mathrm{H}$ bonds of the aromatic ring showed bands near $750 \mathrm{~cm}^{-1}$.

In another work, we evaluated the anthocyanin stability from the roselle calyxes when exposed to microwave energies. Examining the thermal stability of the anthocyanins to determine their possibility to react at microwave energies without being degraded, the anthocyanin extracts were heated at different temperatures $\left(30-80{ }^{\circ} \mathrm{C}\right)$ for $20 \mathrm{~min}$. Afterward, the phenolic compound and chroma properties were spectrophotometrically evaluated. The results showed losses in the total phenolic compounds from 9.28 at $60{ }^{\circ} \mathrm{C}$ to $11.34 \%$ at $80^{\circ} \mathrm{C}$. Meanwhile, color parameters $\mathrm{a}^{*}$ and $\mathrm{b}^{*}$ decreased, but $\mathrm{L}^{*}$ was augmented (lighter colors). The results indicated that the extracts lose their red color by migrating to green $\left(\mathrm{a}^{*}\right)$ and lose their blue color by turning into yellow $\left(\mathrm{b}^{*}\right)$, indicating anthocyanin degradation. With the support of spectrophotometric applications, we can conclude from these results that the temperature increase negatively affects the anthocyanin stability, thereby generating negative repercussions on the nutraceutical and colorant features associated with phenolic compounds [111].

More recently, there are reports concerning the chemical stability of anthocyanins from roselle. Due to D3S being an anthocyanin that has been demonstrated to induce apoptosis in human promyelocytic leukemia cells (HL-60), there has been an increasing interest in the study of the extracts of this plant [112]. The process of copigmentation, highly visible during winemaking, occurs because of the chemical association of two or more anthocyanin molecules, but also with proteins, sugars, organic acids, and other molecules. This process allows the formation of new anthocyanins that exhibit new colors and chemical characteristics. For the above, this study was focused on the aqueous extraction of anthocyanins at different temperatures $\left(40,60\right.$, and $\left.80^{\circ} \mathrm{C}\right)$ and at different times of extraction $(10,20$, and $30 \mathrm{~min})$ to determine the effect of copigmentation with organic acids 
such as phytic and chlorogenic, and $\mathrm{pH}$ on their stability. Anthocyanin $(535 \mathrm{~nm})$, flavonoid $(374 \mathrm{~nm})$, and total phenolic $(761 \mathrm{~nm})$ concentrations and the antioxidant activity were spectrophotometrically analyzed by the DPPH methodology $(517 \mathrm{~nm})$. The results from this study show that anthocyanins from roselle exhibit high thermal stability at $60{ }^{\circ} \mathrm{C}$ and also reversible stability in terms of $\mathrm{pH}$ changes, measured by spectrophotometric titration, thus preserving the antioxidant activity of the extracts evaluated.

Another bioactive compound that has been studied very recently by our research group is piceatannol, a stilbenoid (a nonflavonoid polyphenol) with antiobesity properties that can be characterized, measured, and quantified using spectrophotometric tools. This nutraceutical was extracted from passion fruit seeds (Passiflora edulis) and quantified through the Folin-Ciocalteu methodology at $765 \mathrm{~nm}$, as described earlier (data unpublished). The antioxidant activity was measured by applying the ABTS radical method expressing its antioxidant capacity as $\mu$ mol equivalent Trolox.

Tannins

Tannins are phenolic polymers of plant origin used in leather tanning, since it binds to the collagen proteins of the skin, increasing its resistance to water, heat, and microorganisms; this property is also responsible for generating astringency when they are consumed. They are often found in barks and other plant tissue. We can find them in food grain such as those of some legumes and fruits, such as grapes, among others $[113,114]$. There are two categories of tannins: (1) condensates and (2) hydrolysable (Figure 4). Condensed tannins are compounds formed by the union of flavonoid units of the catechin or flavanonols type. While the hydrolyzable tannins are heterogeneous polymers made up of phenolic acids, mainly gallic acid and simple sugars as the central core; these are smaller than condensed tannins and can be easily hydrolyzed with dilute acids. The strong bond that exists between tannins and proteins is the reason for the indigestibility of these compounds and causes them to be considered without nutritional value; in addition, they can cause a decrease in intake, growth rate, and energy obtained through food, especially in populations whose diets are based on legumes [115].<smiles>O=C(O)c1cc(O)c(O)c(O)c1</smiles>

Hydrolyzable tannin<smiles>OC1Cc2ccccc2OC1c1ccccc1</smiles>

\section{Condensed tannin}

Figure 4. The structures of the main constituents of hydrolyzable tannins and condensed tannins.

Table 1 shows an example of a bioactive tannin, its source, and the most common spectroscopic and spectrometric methods for its identification and quantification.

Terpenes and terpenoids

Terpenes and terpenoids are a group of metabolites widely distributed in nature made up of repeating isoprene units. The compounds of this group comply with the so-called "isoprene rule", which says that terpenes are made up of an integer number of isoprenes joined "head-to-tail" or "head-to-head". However, there are exceptions to this rule derived from some rearrangements that can undergo throughout their biosynthesis. Those compounds that do not strictly comply with this rule, but their structures are modified by one or more rearrangements, are known by the name of terpenoids. These compounds can be cyclic or open-chain and are classified according to the number of isoprenic units that form them: monoterpenes ( 2 units), sesquiterpenes ( 3 units), diterpenes (4 units), sesterpenes (5 units), triterpenes (6 units), and tetraterpenes (8 units) (Figure 5). 
Terpenes have shown a wide variety of biological activities such as antimicrobial [116], antiinflammatory [117], immunomodulatory [118], anticancer [119] activities. Table 1 shows an example of a terpene, its biological activity, the source of this compound, and some common spectroscopic and spectrometric methods used for its identification and quantification.

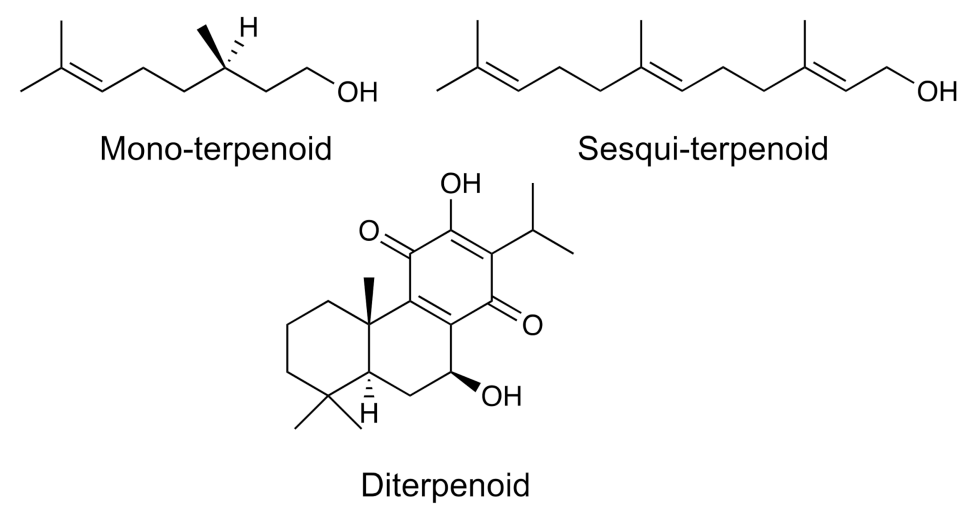

Figure 5. Examples of some terpenes and terpenoids.

More recently, we have been working on the extraction and stabilization of other bioactive compounds, particularly in carotenoids from mamey (Pouteria sapota) and carrot (Daucus carota). These compounds can be spectrophotometrically measured from the extracts obtained from the nonpolar extraction with a mixture of solvents hexane-acetoneethanol. Once extracted, the sample was saponified, and the upper layer was recovered with ethanol to be concentrated in a rotary evaporator. The sample was then analyzed at $450 \mathrm{~nm}$, and the results were compared to a calibration curve prepared using pure $\beta$-carotene. Similar to the analysis performed on the anthocyanins, the carotenoid extracts were tested for antioxidant activity to evaluate the potential use of these vegetal products as beneficial foods with excellent results (data unpublished).

As mentioned earlier, Žilić et al. [86] isolated phenolic compounds and carotenoids from ten different colored maize genotypes. The carotenoids from the maize samples were identified and quantified following the methodology proposed earlier [120]. The carotenoids were extracted from the milled grain by adding $\mathrm{Na}_{2} \mathrm{CO}_{3}$ and a mixture of methanol/ tetrahydrofuran and continuous stirring. The supernatant of the mixture was evaporated and redissolved in the mixture of methanol/tetrahydrofuran to be analyzed by HPLC with a photodiode array detector and a C18 column. The maize samples exhibited the presence of lutein and b-carotene, which were identified by the comparison of the HPLC profiles against the curves previously prepared with the pure standards. As exposed by the authors, the findings of the carotenoid content of maize, particularly provitamin A or b-carotene, reveals the importance of these bioactive compounds in preparing functional foods. One example could be trying to diminish the levels of incidence of vitamin A deficiency, associated with acquired blindness in children, growth retardation, and anemia [121].

Resins

Resins are complex mixtures of compounds such as monoterpenes, diterpenes, triterpenes, polysaccharides, fatty acids, and esters. The compound that prevails depends on the type of resin-for example, mono- and diterpenes prevail in copal resin, polysaccharides, proteins, and terpenes in myrrh, mono- and sesquiterpenes, abietic acid, and other organic acids in turpentine. Some of these resins, such as copal, are used in traditional Mexican medicine to cure headaches, diarrhea, and as anti-inflammatory [122] and in some religious rites. Copal resin contains mono- and sesquiterpenes in its volatile part and triterpenes in its nonvolatile part and may also contain lignans [123]. Myrrh essential oil has antifungal properties [124]. Figure 6 shows the structures of two representative resins, curzerene and 13-epi-manool; additionally, Table 1 exhibits one example of a bioactive resin, its source, and the spectroscopic and spectrometric methods used for its analysis. 
<smiles>C=CC1Cc2c(C)coc2CC1C(=O)O</smiles><smiles>C=CC(C)(O)CC[C@H]1C(=C)CC[C@H]2C(C)(C)CCC[C@]12C</smiles>

\section{3-Epi-manool}

Figure 6. The chemical structure for curzerene and 13-epi-manool, components of myrrh and copal resins, respectively.

\section{Lignans}

Lignans are dimeric phenylpropanoids derived from phenylalanine through cinnamic acid and $p$-coumaric acid (Figure 7). The monomers of the lignans can be synapic acid, ferulic acid, caffeic acid, $p$-coumaryl alcohol, coniferyl alcohol, and synapyl alcohol. Ligans such as podophyllotoxin have been used to treat different cancers [125] as well as other lignans [126]. Table 1 shows an example of bioactive lignan, its source, and the spectroscopic and spectrometric methods used for its analysis.<smiles>COc1cc(CC(CO)C(CO)Cc2ccc(O)c(OC)c2)ccc1O</smiles>

Figure 7. The chemical structure for lignans.

Lignins are formed essentially by oxidative polymerization of various cinnamyl alcohols, corresponding to cinnamic acid. Phenylpropanols are joined to form the polymer by the action of enzymes called peroxidases that catalyze the oxidation of alcohols generating free radicals that combine in non-enzymatic and random processes to give lignin; resulting in a complex and branched structure in all three dimensions. As there is no common repeating unit as in starch, rubber, or cellulose, each lignin molecule can be unique.

Alkaloids

Alkaloids are nitrogenous organic compounds found in $20 \%$ to $30 \%$ of vascular plants. Nitrogen is generally part of a heterocyclic ring. Its name derives from the fact that most of these compounds are alkaline. At the $\mathrm{pH}$ where they are generally found in the cell $(\mathrm{pH}=5-7)$, nitrogen is protonated, so the alkaloid is positively charged and is generally soluble in water. Alkaloids are classified according to their basic structures into derivatives of pyrrolidine, tropane, piperidine, pyrrolizidine, quinolizidine, isoquinoline, and indole (Figure 8). Among the bioactivities they possess are those that affect the central nervous system causing different types of reactions, from sedation, hallucination, and even death. However, there are several that are used in medicine as anesthetics [127], in the treatment of cardiovascular diseases [128]; others showed cytotoxic activity in tumor cells [129]. 
Table 1 summarizes the biological activities of one alkaloid, its source, and methods of identification.<smiles>CN1[C@H]2CC[C@@H]1C[C@@H](OC(=O)C(CO)c1ccccc1)C2</smiles>

Tropane alkaloids<smiles>COc1ccc2cc3[n+](cc2c1OC)CCc1cc2c(cc1-3)OCO2</smiles>

Isoquinoline alkaloids<smiles>[R6]OCC1CCN2CCC([R9])C12</smiles>

Pyrrolizidine alkaloids<smiles>[R6]c1cc[n+](-c2cc(O)ccc2O)cc1C(C)C(C)C</smiles>

Figure 8. The chemical structure for some bioactive group of alkaloids.

Furanocoumarins and naphthodianthrones

Furanocoumarins are heterocyclic compounds that contain a furan ring fused to a coumarin (Figure 9). Furancoumarins such as marmesin are derived from prenylated coumarins and these originate from the ortho-hydroxylation of cinnamic acid, which is rare. Psoralens have been considered to be the phytoalexins that give celery resistance against pathogens, it has also been shown that marmesin (a precursor of psoralens) has antifungal activity in vitro 100 times greater than psoralens. Furthermore, as celery became more susceptible to the pathogen during storage, psoralen levels increased, while marmesin levels decreased. From this, it follows that marmesin is the compound that gives celery resistance against pathogens [130]. Psoralen acts as a skin photosensitizer, causing erythema and darkening of the skin.<smiles>O=c1ccc2ccc3occc3c2o1</smiles>

Furocoumarin<smiles>Cc1cc(O)c2c(=O)c3c(O)cc(O)c4c5c(O)cc(O)c6c(=O)c7c(O)cc(C)c8c1c2c(c34)c(c78)c65</smiles>

Naphtodianthrone (Hypericin)

Figure 9. The chemical structures for hypericin (a naphthodianthrone) and furanocoumarin.

On the other hand, naphthodiantrones are compounds that derive from the polyketide biosynthetic pathway to produce a compound with two anthrone structures fused to a naphthalene skeleton (Figure 9). One of the most relevant compounds of this group is hypericin, which is responsible for the antidepressant, anticancer and antiviral activities of different species of the genus Hypericum [131]. Table 1 shows the biological activity, sources, and methods of identification for a furanocoumarin and a naphtodianthrone. 
Proteins and peptides

Proteins are polymers of amino acids linked by amide bonds called peptide bonds (Figure 10). Proteins can weigh several tens of thousands of daltons and have very varied functions, many of them are specific in an organism, such as the case of enzymes. On the other hand, short chains of amino acids are called peptides or polypeptides. Some organisms can use nonprotein amino acids, known as "rare amino acids" to produce small polypeptides that are toxins such as phalloidin or amanitins, which inhibit RNA polymerase. Amanitins, from Amanita phalloides, are toxins from this fungus that inhibit protein synthesis in mammals; within 6-15 h of ingestion, they cause violent gastroenteritis, fever, tachycardia, hyperglycemia, alteration in electrolyte balance, and liver and kidney dysfunction. They can be lethal. Some of these "rare amino acids" are octopine and nopaline derived from arginine and found in plasmids of Agrobacterium tumefaciens, a tumor-causing pathogen (crown galls) in legumes. Other examples of these amino acids are canavanine, 3,4-dihydroxyphenylalanine, 5-hydroxytryptophan, azetidine-2-carboxylic acid. A characteristic of these "rare amino acids" is that they are very similar to the amino acids used for the biosynthesis of proteins-for example, canavanine with arginine; azetidine-2-carboxylic acid with proline. This means that, in some cases, the toxicity is due to an error in the incorporation of nonprotein amino acid, being mistaken for a protein one, which originates from a nonfunctional protein either because its tertiary structure was modified or because it produced some other change that affects its catalytic property. As extra data, the isoelectric point of canavanine is 8.2 , which makes this amino acid much less basic than arginine, whose isoelectric point is 10.8, which could affect the ability of the enzyme to bind to the substrate or catalyze chemical reactions. Table 1 exemplifies a bioactive peptide isolated and characterized recently.<smiles>[R]C(CNC(=O)C([R])CNC(C)(C)C)C(=O)NCC([R])C(=O)O[Na]</smiles>

Figure 10. The chemical representation for a peptide.

Extraction of bioactive compounds from plants

The obtaining of raw material from plants to evaluate the presence of active principles with beneficial effects on human health is a critical task for researchers. Diverse techniques have been used to obtain biologically active molecules from plants. These applications involve the use of solvents capable of interacting due to their chemical properties. This is the case of the use of critical supercritical fluid extraction (SFE) and pressurized liquid extraction (PLE) methodologies, which, in recent years, have gained notoriety for their ample yields in the extraction of bioactive compounds without causing degradation [132]. Other eco-friendly methodologies have been also applied in this regard-for example, the use of eutectic solvents (DESs) for rapid mechano-chemical extraction of bioactive molecules [133]. Table 2 shows some methodologies used for the extraction of bioactive molecules from plants, their fundaments, and some examples of sources. 
Table 2. Extraction techniques for the obtaining of bioactive compounds from plants.

\begin{tabular}{|c|c|c|c|}
\hline Method of Extraction and Fundamentals & Bioactive Compound & Plant Source & Reference \\
\hline Maceration extraction (ME): & \multirow[b]{2}{*}{ Flavonoid glycoside } & \multirow[b]{2}{*}{ Ginkgo biloba } & \multirow[b]{2}{*}[132,134,135]{} \\
\hline $\begin{array}{l}\text { The plant material is soaked with solvent in a container and left to } \\
\text { stand for a minimum of three days with agitation. The cell wall } \\
\text { softens, releasing the desired material. }\end{array}$ & & & \\
\hline Soxhlet extraction (SE): & \multirow[b]{2}{*}{$\begin{array}{l}\text { Cafestol and kahweol } \\
\text { (diterpenes) }\end{array}$} & \multirow[b]{2}{*}{ Coffea arabica } & \multirow[b]{2}{*}[136,137]{} \\
\hline $\begin{array}{l}\text { The sample is put on a porous filter inside a Soxhlet apparatus } \\
\text { chamber. The solvent is heated reaching its boiling point and } \\
\text { passes through the matrix extracting the desired compound. The } \\
\text { solvent is condensed reaching a volume allowing a siphon effect, } \\
\text { thus continuously using the solvent for the extraction. }\end{array}$ & & & \\
\hline
\end{tabular}

Ultrasound-assisted extraction (UAE):

Waves of high frequencies and longer wavelengths propagating through the medium, causing compression and rarefaction. Bubbles generated are unstable with contracts, collapsing, thus causing cavitation effect that cause cell disruption and improved Resveratrol (flavonoid) Polygonum solvent penetration to the matrix.

\section{Microwave-assisted extraction (MAE):}

Uses microwave energies that interact with dipoles of polar solvents and samples causing heat and allowing the solvent penetration to the matrix. For nonpolar solvents, heating is poor and there is a transfer of the energy by dielectric absorbing.
High-pressure-assisted extraction (HPAE):

High-applied pressure led to increased solubility and produces an increase in permeability. Solvent penetration into the cell is promoted and more target compounds can permeate the cell membrane, facilitating the extraction process.
Supercritical fluid extraction (SFE):

Uses mainly, $\mathrm{CO}_{2}$ as the solvent, which is fluid at $31^{\circ} \mathrm{C}$ and $74 \mathrm{bar}$, dissolving $\mathrm{CO}_{2}$ soluble compounds from plants. A variant is the use of water (SWE) at $100-374{ }^{\circ} \mathrm{C}$ and high pressures to maintain water liquid, allowing to extract polar constituents.
Resveratrol (flavonoid) $\quad \begin{aligned} & \text { Polygonum } \\ & \text { cuspidatum }\end{aligned}$

Pulsed electric field extraction (PEFE) and high voltage electrical discharge extraction (HVED):

Pulses of electricity under high-intensity electric fields are applied to the samples. The cell membranes generate pores that allow the release of intracellular components to the media.

\section{Condensed tannin Stevia rebaudiana $\quad[136,140]$}

$\begin{array}{ccc}\text { Berberine and } & \begin{array}{c}\text { Berberis } \\ \text { jaeschkeana }\end{array}\end{array}$

\section{Cold plasma extraction (CPE):}

Cold plasma causes cell wall damage, an effect that results in the release of active molecules from the cell.

Euglenol,

beta-caryophyllene, alpha-humulene (terpenoids)

Rapid solid-liquid dynamic extraction (RSLDE):

Uses a solid-liquid extractor working at 8-9 bar. Requires water as

a solvent and is based on the principle of pressure/depression.

\section{Carotenoids and} flavonoids
Clove

$[132,140-142]$

\section{Eutectic solvent extraction (ESE):}

Uses environmentally friendly solvents for the extraction of bioactive compounds from plants. This kind of solvents is prepared when two solid compounds are mixed under certain conditions to diminish their melting points to a point low to form a eutectic mixture with specific physicochemical characteristics.
Polyphenols
Wolfberry
[139,144,145] 
Table 2. Cont.

\begin{tabular}{|c|c|c|c|}
\hline Method of Extraction and Fundamentals & Bioactive Compound & Plant Source & Reference \\
\hline \multicolumn{4}{|l|}{ Enzyme-assisted extraction (EAE): } \\
\hline $\begin{array}{l}\text { Pretreatment for the extraction that uses enzymes with specific } \\
\text { activities, promoting disruption of the cell wall of the plant } \\
\text { material to enhance or facilitate the solvent extraction of the } \\
\text { biologically active compound. }\end{array}$ & Proanthocyanidins & Grapes & {$[150,151]$} \\
\hline
\end{tabular}

\section{Conclusions}

Our group has been working successfully with diverse vegetal extracts rich in polyphenols and anthocyanins, which have nutraceutical properties that are relevant in the food industry. The separation and the quantification of separation by chromatographic methods such as GC and HPLC combined with spectroscopic and spectrometric techniques, such as UV-vis, IR, and MS, are relevant in the characterization and quantification of natural polyphenols, anthocyanins, and synthetic derivatives, as we have shown through several examples.

Author Contributions: All authors contributed equally to this work. All authors have read and agreed to the published version of the manuscript.

Funding: This research received no external funding.

Institutional Review Board Statement: Not applicable.

Informed Consent Statement: Not applicable.

Data Availability Statement: Data of this article are available from the corresponding author upon reasonable request.

Conflicts of Interest: The authors declare no conflict of interest.

\section{References}

1. Wadood, S.A.; Boli, G.; Zhang, X.W.; Hussain, I.; Wei, Y.M. Recent development in the application of analytical techniques for the traceability and authenticity of food of plant origin. Microchem. J. 2020, 152, 104295. [CrossRef]

2. Lindinger, W.; Hansel, A.; Jordan, A. On-line monitoring of volatile organic compounds at pptv levels by means of proton-transfer reaction mass spectrometry (PTR-MS) medical applications, food control and environmental research. Int. J. Mass Spectrom. 1998, 173, 191-241. [CrossRef]

3. Yang, X.; Neta, P.; Stein, S.E. Extending a tandem mass spectral library to include MS2 spectra of fragment ions produced in-source and MSn spectra. J. Am. Soc. Mass Spectrom. 2017, 28, 2280-2287. [CrossRef] [PubMed]

4. Conceição, R.S.; Perez, C.J.; Branco, A.; Botura, M.B.; Ifa, D.R. Identification of Sassafras albidum alkaloids by high-performance thin-layer chromatography tandem mass spectrometry and mapping by desorption electrospray ionization mass spectrometry imaging. J. Mass Spectrom. 2020, e4674. [CrossRef]

5. Govindaraj, N.; Gangadoo, S.; Truong, V.K.; Chapman, J.; Gill, H.; Cozzolino, D. The use of derivatives and chemometrics to interrogate the UV-Visible spectra of gin samples to monitor changes related to storage. Spectrochim. Acta A Mol. Biomol. Spectrosc. 2020, 227, 117548. [CrossRef]

6. $\quad$ Emwas, A.H.; Roy, R.; McKay, R.T.; Tenori, L.; Saccenti, E.; Gowda, G.A.; Raftery, D.; Alahmari, F.; Jaremko, L.; Jaremko, M.; et al. NMR spectroscopy for metabolomics research. Metabolites 2019, 9, 123. [CrossRef]

7. Wallace, R.J. Antimicrobial properties of plant secondary metabolites. Proc. Nutr. Soc. 2004, 63, 621-629. [CrossRef]

8. Seca, A.M.; Pinto, D.C. Plant secondary metabolites as anticancer agents: Successes in clinical trials and therapeutic application. Int. J. Mol. Sci. 2018, 19, 263. [CrossRef]

9. Kong, J.M.; Chia, L.S.; Goh, N.K.; Chia, T.F.; Brouillard, R. Analysis and biological activities of anthocyanins. Phytochemistry 2003, 64, 923-933. [CrossRef]

10. Bernhoft, A. A brief review on bioactive compounds in plants. In Bioactive Compounds in Plants-Benefits and Risks for Man and Animals; Bernhoft, A., Ed.; The Norwegian Academy of Science and Letters: Oslo, Norway, 2010.

11. Zhao, M.; Bai, L.; Wang, L.; Toki, A.; Hasegawa, T.; Kikuchi, M.; Abe, M.; Sakai, J.; Hasegawa, R.; Bai, Y.; et al. Bioactive cardenolides from the stems and twigs of Nerium oleander. J. Nat. Prod. 2007, 70, 1098-1103. [CrossRef]

12. Binienda, A.; Ziolkowska, S.; Pluciennik, E. The anticancer properties of silibinin: Its molecular mechanism and therapeutic effect in breast cancer. Anticancer Agents Med. Chem. 2020, 20, 1787-1796. [CrossRef] [PubMed] 
13. Gillessen, A.; Schmidt, H.H.J. Silymarin as Supportive Treatment in Liver Diseases: A Narrative Review. Adv. Ther. 2020, 37, 1279-1301. [CrossRef] [PubMed]

14. Elateeq, A.A.; Sun, Y.; Nxumalo, W.; Gabr, A.M. Biotechnological production of silymarin in Silybum marianum L.: A review. Biocatal. Agric. Biotechnol. 2020, 29, 101775. [CrossRef]

15. Petrásková, L.; Káňová, K.; Biedermann, D.; Křen, V.; Valentová, K. Simple and Rapid HPLC Separation and Quantification of Flavonoid, Flavonolignans, and 2,3-Dehydroflavonolignans in Silymarin. Foods 2020, 9, 116. [CrossRef]

16. Rauf, A.; Imran, M.; Abu-Izneid, T.; Patel, S.; Pan, X.; Naz, S.; Silva, A.S.; Saeed, F.; Suleria, H.A.R. Proanthocyanidins: A comprehensive review. Biomed. Pharmacother. 2019, 116, 108999. [CrossRef]

17. Reeves, S.G.; Somogyi, A.; Zeller, W.E.; Ramelot, T.A.; Wrighton, K.C.; Hagerman, A.E. Proanthocyanidin Structural Details Revealed by Ultrahigh Resolution FT-ICR MALDI-Mass Spectrometry, 1H-13C HSQC NMR, and Thiolysis-HPLC-DAD. J. Agric. Food Chem. 2020, 68, 14038-14048. [CrossRef]

18. Mattio, L.M.; Catinella, G.; Dallavalle, S.; Pinto, A. Stilbenoids: A Natural Arsenal against Bacterial Pathogens. Antibiotics 2020, 9 , 336. [CrossRef]

19. Kim, H.W.; Kim, S.S.; Kang, K.B.; Ryu, B.; Park, E.; Huh, J.; Jeon, W.K.; Chae, H.-S.; Oh, W.K.; Kim, J.; et al. Combined MS/MSNMR Annotation Guided Discovery of Iris lactea var. chinensis Seed as a Source of Viral Neuraminidase Inhibitory Polyphenols. Molecules 2020, 25, 3383. [CrossRef]

20. Watrelot, A.A.; Norton, E.L. Chemistry and Reactivity of Tannins in Vitis spp.: A Review. Molecules 2020, 25, 2110. [CrossRef]

21. Cardullo, N.; Muccilli, V.; Cunsolo, V.; Tringali, C. Mass Spectrometry and 1H-NMR Study of Schinopsis lorentzii (Quebracho) Tannins as a Source of Hypoglycemic and Antioxidant Principles. Molecules 2020, 25, 3257. [CrossRef]

22. Yu, L.; Yan, J.; Sun, Z. D-limonene exhibits anti-inflammatory and antioxidant properties in an ulcerative colitis rat model via regulation of iNOS, COX-2, PGE2 and ERK signaling pathways. Mol. Med. Rep. 2017, 15, 2339-2346. [CrossRef]

23. John, I.; Muthukumar, K.; Arunagiri, A. A review on the potential of citrus waste for D-Limonene, pectin, and bioethanol production. Int. J. Green Energy 2017, 14, 599-612. [CrossRef]

24. Bsaibes, S.; Piel, F.; Gros, V.; Truong, F.; Lafouge, F.; Ciuraru, R.; Buysse, P.; Kammer, J.; Loubet, B.; Staudt, M. Monoterpene Chemical Speciation with High Time Resolution Using a FastGC/PTR-MS: Results from the COV3ER Experiment on Quercus ilex. Atmosphere 2020, 11, 690. [CrossRef]

25. Rana, V.S.; Ahluwalia, V.; Shakil, N.A.; Prasad, L. Essential oil composition, antifungal, and seedling growth inhibitory effects of zerumbone from Zingiber zerumbet Smith. J. Essent. Oil Res. 2017, 29, 320-329. [CrossRef]

26. Girisa, S.; Shabnam, B.; Monisha, J.; Fan, L.; Halim, C.E.; Arfuso, F.; Ahn, K.S.; Sethi, G.; Kunnumakkara, A.B. Potential of Zerumbone as an Anti-Cancer Agent. Molecules 2019, 24, 734. [CrossRef] [PubMed]

27. Srikrishna, D.; Godugu, C.; Dubey, P.K. A review on pharmacological properties of coumarins. Mini Rev. Med. Chem. 2018, 18, 113-141. [CrossRef]

28. Gonçalves, G.A.; Spillere, A.R.; Machado das Neves, G.; Kagami, L.P.; Lino von Poser, G.; Santos Canto, R.F.; Eifler-Lima, V.L. Natural and synthetic coumarins as antileishmanial agents: A review. Eur. J. Med. Chem. 2020, 203, 112514. [CrossRef] [PubMed]

29. Majhi, S. Diterpenoids: Natural Distribution, Semisynthesis at Room Temperature and Pharmacological Aspects-A Decade Update. Chem. Sel. 2020, 15, 1-16. [CrossRef]

30. Yilmaz, A.; Crowley, R.S.; Sherwood, A.M.; Prisinzano, T.E. Semisynthesis and kappa-opioid receptor activity of derivatives of columbin, a furanolactone diterpene. J. Nat. Prod. 2017, 80, 2094-2100. [CrossRef]

31. Islam, A.K.M.M.; Hong, S.M.; Lee, H.S.; Moon, B.C.; Kim, D.; Kwon, H. Identification and characterization of matrix components in spinach during QuEChERS sample preparation for pesticide residue analysis by LC-ESI-MS/MS, GC-MS and UPLC-DAD. J. Food Sci. Technol. 2018, 55, 3930-3938. [CrossRef]

32. Dai, Y.; Row, K.H. Isolation and determination of beta-carotene in carrots by magnetic chitosan beta-cyclodextrin extraction and high-performance liquid chromatography (HPLC). Anal. Lett. 2019, 52, 1828-1843. [CrossRef]

33. Horst, D.J.; Tebcherani, S.M.; Kubaski, E.T.; de Almeida Vieira, R. Bioactive Potential of 3D-Printed Oleo-Gum-Resin Disks: B. papyrifera, C. myrrha, and S. benzoin Loading Nanooxides- $\mathrm{TiO}_{2}, \mathrm{P} 25, \mathrm{Cu}_{2} \mathrm{O}$, and $\mathrm{MoO}_{3}$. Bioinorg. Chem. Appl. 2017, $2017,6398167$. [CrossRef] [PubMed]

34. Wang, F.; Zhang, L.; Zhang, Q.; Chen, A.; Wang, S.; Fang, Z. Two new phenylpropanoids from the resin of Styrax tonkinensis (Pierre) Craib ex Hartw. J. Nat. Med. 2020, 74, 819-824. [CrossRef]

35. Cui, Q.; Du, R.; Liu, M.; Rong, L. Lignans and Their Derivatives from Plants as Antivirals. Molecules 2020, 25, 183. [CrossRef]

36. Liu, B.; Yang, Y.; Liu, H.; Xie, Z.; Li, Q.; Deng, M.; Li, F.; Peng, J.; Wu, H. Screening for cytotoxic chemical constituents from Justicia procumbens by HPLC-DAD-ESI-MS and NMR. Chem. Cent. J. 2018, 12, 1-15. [CrossRef] [PubMed]

37. Debnath, B.; Singh, W.S.; Das, M.; Goswami, S.; Singh, M.K.; Maiti, D.; Manna, K. Role of plant alkaloids on human health: A review of biological activities. Mater. Today Chem. 2018, 9, 56-72. [CrossRef]

38. Kopp, T.; Abdel-Tawab, M.; Mizaikoff, B. Extracting and Analyzing Pyrrolizidine Alkaloids in Medicinal Plants: A Review. Toxins 2020, 12, 320. [CrossRef] [PubMed]

39. Melough, M.M.; Cho, E.; Chun, O.K. Furocoumarins: A review of biochemical activities, dietary sources and intake, and potential health risks. Food Chem Toxicol. 2018, 113, 99-107. [CrossRef] 
40. Bruni, R.; Barreca, D.; Protti, M.; Brighenti, V.; Righetti, L.; Anceschi, L.; Mercolini, L.; Benvenuti, S.; Gattuso, G.; Pellati, F. Botanical Sources, Chemistry, Analysis, and Biological Activity of Furanocoumarins of Pharmaceutical Interest. Molecules 2019, 24, 2163. [CrossRef]

41. Mir, M.Y.; Hamid, S.; Kamili, A.N.; Hassan, Q.P. Sneak peek of Hypericum perforatum L.: Phytochemistry, phytochemical efficacy and biotechnological interventions. J. Plant Biochem. Biotechnol. 2019, 28, 357-373. [CrossRef]

42. Kimáková, K.; Kimáková, A.; Idkowiak, J.; Stobiecki, M.; Rodziewicz, P.; Marczak, Ł.; Čellárová, E. Phenotyping the genus Hypericum by secondary metabolite profiling: Emodin vs. skyrin, two possible key intermediates in hypericin biosynthesis. Anal. Bioanal. Chem. 2018, 410, 7689-7699. [CrossRef]

43. Hayes, M.; Bleakley, S. 21 Peptides from plants and their applications. In Peptide Applications in Biomedicine, Biotechnology and Bioengineering; Koutsopoulos, S., Ed.; Woodhead Publishing: Sawston, UK, 2018; pp. 603-622. [CrossRef]

44. Fideler, J.; Johanningsmeier, S.D.; Ekelöf, M.; Muddiman, D.C. Discovery and quantification of bioactive peptides in fermented cucumber by direct analysis IR-MALDESI mass spectrometry and LC-QQQ-MS. Food Chem. 2019, 271, 715-723. [CrossRef]

45. Kumar, K.K.; Chandra, K.L.P.; Sumanthi, J.; Reddy, G.S.; Shekar, P.C.; Reddy, B.V.R. Biological role of lectins: A review. J. Orofac. Sci. 2012, 4, 20. [CrossRef]

46. Gnanesh Kumar, B.S.; Surolia, A. Identification of Banana Lectin Isoforms and Differential Acetylation through Mass Spectrometry Approaches. Prot. J. 2017, 37, 38-46. [CrossRef] [PubMed]

47. Hong, V.; Wrolstad, R.E. Use of HPLC separation/photodiode array detection for characterization of anthocyanins. J. Agric. Food Chem. 1990, 38, 708-715. [CrossRef]

48. Chen, L.; Xin, X.; Feng, H.; Li, S.; Cao, Q.; Wang, X.; Vriesekoop, F. Isolation and Identification of Anthocyanin Component in the Fruits of Acanthopanax sessiliflorus (Rupr. \& Maxim.) Seem. by Means of High-Speed Counter Current Chromatography and Evaluation of Its Antioxidant Activity. Molecules 2020, 25, 1781. [CrossRef]

49. Wang, L.S.; Stoner, G.D. Anthocyanins and their role in cancer prevention. Cancer Lett. 2008, 269, 281-290. [CrossRef] [PubMed]

50. Mourtzinos, I.; Makris, D.P.; Yannakopoulou, K.; Kalogeropoulos, N.; Michali, I.; Karathanos, V.T. Thermal Stability of Anthocyanin Extract of Hibiscus sabdariffa L. in the Presence of $\beta$-Cyclodextrin. J. Agric. Food Chem. 2008, 56, 10303-10310. [CrossRef] [PubMed]

51. Bonvehí, J.S.; Coll, F.V. Phenolic composition of propolis from China and from South America. Z. Naturforsch. C 1994, 49, 712-718. [CrossRef]

52. Jiménez-Martínez, M.D.; Bautista-Ortín, A.B.; Gil-Muñoz, R.; Gómez-Plaza, E. Fining with purified grape pomace. Effect of dose, contact time and varietal origin on the final wine phenolic composition. Food Chem. 2019, 271, 570-576. [CrossRef]

53. Folin, O.; Ciocalteu, V. Tyrosine and tryptophan determinations proteins. J. Biol. Chem. 1927, 73, 627. [CrossRef]

54. Singleton, V.L.; Orthofer, R.; Lamuela-Raventos, R.M. Analysis of total phenols and other oxidation substrates and antioxidants by means of Folin-Ciocalteu reagent. Meth. Enzymol. 1999, 299, 152-178. [CrossRef]

55. Jiménez-Aguilar, D.M.; Ortega-Regules, A.E.; Lozada-Ramírez, J.D.; Pérez-Pérez, M.C.I.; Vernon-Carter, E.J.; Welti-Chanes, J. Color and chemical stability of spray-dried blueberry extract using mesquite gum as wall material. J. Food Compost. Anal. 2011, 24, 889-894. [CrossRef]

56. Lee, J.; Durst, R.W.; Wrolstad, R.E. Determination of total monomeric anthocyanin pigment content of fruit juices, beverages, natural colorants, and wines by the $\mathrm{pH}$ differential method: Collaborative study. J. AOAC Int. 2005, 88, 1269-1278. [CrossRef] [PubMed]

57. Sarni-Manchado, P.; Fulcrand, H.; Souquet, J.M.; Cheynier, V.; Moutounet, M. Stability and color of unreported wine anthocyaninderived pigments. J. Food Sci. 1996, 61, 938-941. [CrossRef]

58. Boulton, R. The copigmentation of anthocyanins and its role in the color of red wine: A critical review. Am. J. Enol. Vitic. 2001, 52, 67-87.

59. Osete-Alcaraz, A.; Bautista-Ortín, A.B.; Ortega-Regules, A.; Gómez-Plaza, E. Elimination of suspended cell wall material in musts improves the phenolic content and color of red wines. Am. J. Enol. Vitic. 2019, 70, 201-204. [CrossRef]

60. Ortega-Regules, A.; Romero-Cascales, I.; García, J.M.R.; Bautista-Ortín, A.B.; López-Roca, J.M.; Fernández-Fernández, J.I.; GómezPlaza, E. Anthocyanins and tannins in four grape varieties (Vitis vinifera L.). Evolution of their content and extractability. OENO One 2008, 42, 147-156. [CrossRef]

61. Bautista-Ortín, A.B.; Martínez-Hernández, A.; Ruiz-García, Y.; Gil-Muñoz, R.; Gómez-Plaza, E. Anthocyanins influence tannin-cell wall interactions. Food Chem. 2016, 206, 239-248. [CrossRef]

62. Gómez-Plaza, E.; Osete-Alcaraz, A.; Jurado, R.; Iniesta, J.A.; Bautista-Ortín, A.B. The application of high power ultrasounds for improving the phenolic extraction and color from grape-derived products. Acta Hortic. 2020, 1274, 1-8. [CrossRef]

63. Reiter, R.J. Oxidative processes and antioxidative defense mechanisms in the aging brain 1. FASEB J. 1995, 9, 526-533. [CrossRef] [PubMed]

64. Sherer, T.B.; Betarbet, R.; Stout, A.K.; Lund, S.; Baptista, M.; Panov, A.V.; Cookson, M.R.; Greenamyre, J.T. An in vitro model of Parkinson's disease: Linking mitochondrial impairment to altered $\alpha$-synuclein metabolism and oxidative damage. J. Neurosci. 2002, 22, 7006-7015. [CrossRef]

65. Apel, K.; Hirt, H. Reactive oxygen species: Metabolism, oxidative stress, and signal transduction. Annu. Rev. Plant. Biol. 2004, 55, 373-399. [CrossRef] 
66. Rius-Pérez, S.; Torres-Cuevas, I.; Millán, I.; Ortega, Á.L.; Pérez, S. PGC-1 $\alpha$, Inflammation, and Oxidative Stress: An Integrative View in Metabolism. Oxidative Med. Cell. Longev. 2020, 2020, 1452696. [CrossRef] [PubMed]

67. Flora, S.J. Structural, chemical and biological aspects of antioxidants for strategies against metal and metalloid exposure. Oxidative Med. Cell. Longev. 2009, 2, 191-206. [CrossRef] [PubMed]

68. Brand-Williams, W.; Cuvelier, M.E.; Berset, C. Use of free radical method to evaluate antioxidant activity. Lebensm. Wiss. Technol. 1995, 28, 25-30. [CrossRef]

69. Re, R.; Pellegrini, N.; Proteggente, A.; Pannala, A.; Yang, M.; Rice-Evans, C. Antioxidant activity applying an improved ABTS radical cation decolorization assay. Free Radic. Biol. Med. 1999, 26, 1231-1237. [CrossRef]

70. Schlesier, K.; Harwat, M.; Böhm, V.; Bitsch, R. Assessment of antioxidant activity by using different in vitro methods. Free Radic. Res. 2002, 36, 177-187. [CrossRef]

71. Huang, D.; Ou, B.; Prior, R.L. The chemistry behind antioxidant capacity assays. J. Agric. Food Chem. 2005, 53, 1841-1856. [CrossRef]

72. Benzie, I.F.F.; Strain, J.J. The ferric reducing ability of plasma as a measure of "antioxidant power": The FRAP assay. Anal. Biochem. 1996, 239, 70-76. [CrossRef]

73. Cao, G.; Alessio, H.M.; Cutler, R.G. Oxygen-radical absorbance capacity assay for antioxidants. Free Radic. Biol. Med. 1993, 14, 303-311. [CrossRef]

74. Miller, N.J.; Rice-Evans, C.; Davies, M.J.; Gopinathan, V.; Milner, A. A novel method for measuring antioxidant capacity and its application to monitoring the antioxidant status in premature neonates. Clin. Sci. 1993, 84, 407-412. [CrossRef] [PubMed]

75. Fogliano, V.; Verde, V.; Randazzo, G.; Ritieni, A. Method for measuring antioxidant activity and its application to monitoring the antioxidant capacity of wines. J. Agric. Food Chem. 1999, 47, 1035-1040. [CrossRef] [PubMed]

76. Apak, R.; Güçlü, K.; Ozyürek, M.; Oğlu, B.B.; Bener, M. Cupric ion reducing antioxidant capacity assay for food antioxidants: Vitamins, polyphenolics, and flavonoids in food extracts. Methods Mol. Biol. 2008, 477, 163-193. [CrossRef]

77. Hidalgo, G.I.; Almajano, M.P. Red Fruits: Extraction of Antioxidants, Phenolic Content, and Radical Scavenging Determination: A Review. Antioxidants 2017, 6, 7. [CrossRef]

78. Metzner, C.R.; Lupitu, A.I.; Moisa, C.; Rivis, A.; Copolovici, L.O.; Poiana, M.A. Investigation on High-Value Bioactive Compounds and Antioxidant Properties of Blackberries and Their Fractions Obtained by Home-Scale Juice Processing. Sustainability 2020, 12, 5681. [CrossRef]

79. Magrone, T.; Magrone, M.; Russo, M.A.; Jirillo, E. Recent Advances on the Anti-Inflammatory and Antioxidant Properties of Red Grape Polyphenols: In Vitro and In Vivo Studies. Antioxidants 2020, 9, 35. [CrossRef]

80. Ljevar, A.; Ćurko, N.; Tomašević, M.; Radošević, K.; Srček, V.G.; Ganić, K.K. Phenolic Composition, Antioxidant Capacity and in vitro Cytotoxicity Assessment of Fruit Wines. Food Technol. Biotechnol. 2016, 54, 145-155. [CrossRef]

81. Nie, X.R.; Li, H.Y.; Wei, S.Y.; Han, Q.H.; Zhao, L.; Zhang, Q.; Li, S.Q.; Qin, W.; Wu, D.T. Changes of phenolic compounds, antioxidant capacities, and inhibitory effects on digestive enzymes of kiwifruits (Actinidia chinensis) during maturation. J. Food Meas. Charact. 2020, 14, 1765-1774. [CrossRef]

82. Tong, T.; Liu, Y.J.; Kang, J.; Zhang, C.M.; Kang, S.G. Antioxidant Activity and Main Chemical Components of a Novel Fermented Tea. Molecules 2019, 24, 2917. [CrossRef]

83. Kim, H.J.; Kim, B.; Mun, E.G.; Jeong, S.Y.; Cha, Y.S. The antioxidant activity of steamed ginger and its protective effects on obesity induced by high-fat diet in C57BL/6J mice. Nutr. Res. Pract. 2018, 12, 503-511. [CrossRef]

84. Ahmad, T.; Cawood, M.; Iqbal, Q.; Ariño, A.; Batool, A.; Tariq, R.; Azam, M.; Akhtar, S. Phytochemicals in Daucus carota and Their Health Benefits-Review Article. Foods 2019, 8, 424. [CrossRef]

85. Park, J.H.; Lee, Y.J.; Kim, Y.H.; Yoon, K.S. Antioxidant and Antimicrobial Activities of Quinoa (Chenopodium quinoa Willd.) Seeds Cultivated in Korea. Prev. Nutr. Food Sci. 2017, 22, 195-202. [CrossRef] [PubMed]

86. Žilić, S.; Serpen, A.; Akıllıŏlu, G.; Gökmen, V.; Vančetović, J. Phenolic compounds, carotenoids, anthocyanins, and antioxidant capacity of colored maize (Zea mays L.) kernels. J. Agric. Food Chem. 2012, 60, 1224-1231. [CrossRef]

87. Francavilla, A.; Joye, I.J. Anthocyanins in Whole Grain Cereals and Their Potential Effect on Health. Nutrients 2020, 12, 2922. [CrossRef]

88. Goh, L.M.; Barlow, P.J. Antioxidant capacity in Ginkgo biloba. Food Res. Int. 2002, 35, 815-820. [CrossRef]

89. Estupiñán, D.C.; Schwartz, S.J.; Garzón, G.A. Antioxidant activity, total phenolics content, anthocyanin, and color stability of isotonic model beverages colored with andes berry (Rubus glaucus Benth) anthocyanin powder. J. Food Sci. 2011, 76, S26-S34. [CrossRef] [PubMed]

90. Tsai, P.J.; McIntosh, J.; Pearce, P.; Camden, B.; Jordan, B.R. Anthocyanin and antioxidant capacity in Roselle (Hibiscus Sabdariffa, L.) extract. Food Res. Int. 2002, 35, 351-356. [CrossRef]

91. Fernández-Arroyo, S.; Rodríguez-Medina, I.C.; Beltrán-Debón, R.; Pasini, F.; Joven, J.; Micol, V.; Segura-Carretero, A.; FernándezGutiérrez, A. Quantification of the polyphenolic fraction and in vitro antioxidant and in vivo anti-hyperlipemic activities of Hibiscus sabdariffa aqueous extract. Food Res. Int. 2011, 44, 1490-1495. [CrossRef]

92. Owoade, A.O.; Lowe, G.M.; Khalid, R. The in vitro antioxidant properties of Hibiscus anthocyanins rich extract (HAE). Nat. Sci. 2015, 13, 22-29.

93. Cissé, M.; Bohuon, P.; Sambe, F.; Kane, C.; Sakho, M.; Dornier, M. Aqueous extraction of anthocyanins from Hibiscus sabdariffa: Experimental kinetics and modeling. J. Food Eng. 2012, 109, 16-21. [CrossRef] 
94. Lao, F.; Giusti, M.M. The effect of pigment matrix, temperature and amount of carrier on the yield and final color properties of spray dried purple corn (Zea mays L.) cob anthocyanin powders. Food Chem. 2017, 227, 376-382. [CrossRef] [PubMed]

95. Araujo, N.M.P.; Arruda, H.S.; Dos Santos, F.N.; de Morais, D.R.; Pereira, G.A.; Pastore, G.M. LC-MS/MS screening and identification of bioactive compounds in leaves, pulp and seed from Eugenia calycina Cambess. Food Res. Int. 2020, $137,109556$. [CrossRef]

96. Li, H.W.; Liu, P.; Zhang, H.Q.; Feng, W.M.; Yan, H.; Guo, S.; Qian, D.; Duan, J.A. Determination of bioactive compounds in the nonmedicinal parts of Scrophularia ningpoensis using ultra-high-performance liquid chromatography coupled with tandem mass spectrometry and chemometric analysis. J. Sep. Sci. 2020, 43, 4191-4201. [CrossRef] [PubMed]

97. Różańska, A.; Russo, M.; Cacciola, F.; Salafia, F.; Polkowska, Ż.; Dugo, P.; Mondello, L. Concentration of potentially bioactive compounds in italian extra virgin olive oils from various sources by using LC-MS and multivariate data analysis. Foods 2020, 9 , 1120. [CrossRef]

98. Russo, M.; Cacciola, F.; Arena, K.; Mangraviti, D.; de Gara, L.; Dugo, P.; Mondello, L. Characterization of the polyphenolic fraction of pomegranate samples by comprehensive two-dimensional liquid chromatography coupled to mass spectrometry detection. Nat. Prod. Res. 2020, 34, 39-45. [CrossRef] [PubMed]

99. Zhishen, J.; Mengcheng, T.; Jianming, W. The determination of flavanoid contents in mulberry and their scavenging effects on superoxid radicals. Food Chem. 1999, 64, 555-559. [CrossRef]

100. Urias-Lugo, D.A.; Heredia, J.B.; Muy-Rangel, M.D.; Valdez-Torres, J.B.; Serna-Saldivar, S.O.; Gutiérrez-Uribe, J.A. Anthocyanins and Phenolic Acids of Hybrid and Native Blue Maize (Zea mays L.) Extracts and Their Antiproliferative Activity in Mammary (MCF7), Liver (HepG2), Colon (Caco2 and HT29) and Prostate (PC3) Cancer Cells. Plant. Food Hum. Nutr. 2015, 70, 193-199. [CrossRef]

101. Yang, Z.; Chen, Z.; Yuan, S.; Zhai, W.; Piao, X. Extraction and identification of anthocyanin from purple corn (Zea mays L.). Int. J. Sci. Technol. 2009, 44, 2485-2492. [CrossRef]

102. Dewanto, V.; Wu, X.; Liu, R.H. Processed sweet corn has higher antioxidant activity. J. Agric. Food Chem. 2002, 50, $4959-4964$. [CrossRef]

103. De Pascual-Teresa, S.; Santos-Buelga, C.; Rivas-Gonzalo, J.C. LC-MS analysis of anthocyanins from purple corn cob. J. Sci. Food Agric. 2002, 82, 1003-1006. [CrossRef]

104. Fossen, T.; Slimestad, R.; Andersen, Ø.M. Anthocyanins from Maize (Zea mays) and Reed Canarygrass (Phalaris arundinacea). J. Agric. Food Chem. 2001, 49, 2318-2321. [CrossRef] [PubMed]

105. Gođevac, D.; Tešević, V.; Veličković, M.; Vujisić, L.; Vajs, V.; Milosavljević, S. Polyphenolic compounds in seeds from some grape cultivars grown in Serbia. J. Serb. Chem. Soc. 2010, 75, 1641-1652. [CrossRef]

106. Yonekura-Sakakibara, K.; Fukushima, A.; Nakabayashi, R.; Hanada, K.; Matsuda, F.; Sugawara, S.; Inoue, E.; Kuromori, T.; Ito, T.; Shinozaki, K.; et al. Two glycosyltransferases involved in anthocyanin modification delineated by transcriptome independent component analysis in Arabidopsis thaliana. Plant J. 2012, 69, 154-167. [CrossRef] [PubMed]

107. Du, H.; Wu, J.; Ji, K.X.; Zeng, Q.Y.; Bhuiya, M.W.; Su, S.; Shu, Q.Y.; Ren, H.X.; Liu, Z.A.; Wang, L.S. Methylation mediated by an anthocyanin, O-methyltransferase, is involved in purple flower coloration in Paeonia. J. Exp. Bot. 2015, 66, 6563-6577. [CrossRef]

108. Guzmán-Figueroa, M.D.P.; Ortega-Regules, A.E.; Bautista-Ortín, A.B.; Gómez-Plaza, E.; Anaya-Berríos, C. New pyranoanthocyanins synthesized from roselle (Hibiscus sabdariffa L.) anthocyanins. J. Mex. Chem. Soc. 2016, 60, 13-18. [CrossRef]

109. Santillán-Urquiza, E.; Méndez-Rojas, M.Á.; Vélez-Ruiz, J.F. Fortification of yogurt with nano and micro sized calcium, iron and zinc, effect on the physicochemical and rheological properties. LWT 2017, 80, 462-469. [CrossRef]

110. Martínez-Pacheco, M.; Lozada-Ramírez, J.D.; Martínez-Huitle, C.A.; Cerro-López, M. Hibiscus sabdariffa L. Anthocyanins Immobilization on $\mathrm{TiO} 2$ Nanotubes and Its Electrochemical Characterization as a Hydrogen Peroxide Sensing Electrode. J. Electrochem. Soc. 2019, 166, B1506. [CrossRef]

111. Hid-Cadena, R.H.; Bautista-Ortín, A.B.; Ortega-Regules, A.E.; Welti-Chanes, J.; Lozada-Ramírez, J.D.; Anaya de Parrodi, C. Cambios en contenido de compuestos fenólicos y color de extractos de Jamaica (Hibiscus sabdariffa) sometidos a calentamiento con energía de microondas. In Proceedings of the IX Congreso Nacional del Color, Alicante, Spain, 29 June-2 July 2010; Publicaciones de la Universidad de Alicante: Madrid, Spain, 2010; pp. 300-303. (In Spanish).

112. Maciel, L.G.; do Carmo, M.A.V.; Azevedo, L.; Daguer, H.; Molognoni, L.; de Almeida, M.M.; Granato, D.; Rosso, N.D. Hibiscus sabdariffa anthocyanins-rich extract: Chemical stability, in vitro antioxidant and antiproliferative activities. Food Chem. Toxicol. 2018, 113, 187-197. [CrossRef]

113. Deshpande, S.S.; Sathe, S.K.; Salunkhe, D.K. Chemistry and safety of plant phenols. Adv. Exp. Med. Biol. 1984, 177, 457-495. [CrossRef]

114. Thompson, R.J.; Jacques, D.; Haslam, E.; Tanner, R.J.N. Plant proanthocyanidins. I. Introduction: The isolation, structure and distribution in nature of plant procyanidins. J. Chem. Soc. Perkins Trans. 1972, 1387-1399. [CrossRef]

115. Chung, K.T.; Wong, T.Y.; Wei, C.I.; Huang, Y.W.; Lin, Y. Tannins and Human Health: A Review. Crit. Rev. Food Sci. Nutr. 1998, 38, 421-464. [CrossRef]

116. Guoruoluo, Y.; Zhou, H.; Zhou, J.; Zhao, H.; Aisa, H.A.; Yao, G. Isolation and characterization of sesquiterpenoids from Cassia buds and their antimicrobial activities. J. Agric. Food Chem. 2017, 65, 5614-5619. [CrossRef] [PubMed] 
117. Kabir, T.; Uddin, S.; Zaman, S.; Rahman, S.; Behl, T.; Ahmad, A.; Hafeez, A.; Perveen, A.; Ashraf, G. Exploring the AntiNeuroinflammatory Potential of Steroid and Terpenoid-Derived Phytochemicals to Combat Alzheimer's Disease. Curr. Pharm. Des. 2020, 26, 1-15. [CrossRef]

118. Zhou, H.; Guoruoluo, Y.; Tuo, Y.; Zhou, J.; Zhang, H.; Wang, W.; Xiang, M.; Aisa, H.A.; Yao, G. Cassiabudanols A and B, immunostimulative diterpenoids with a Cassiabudane carbon skeleton featuring a 3-oxatetracyclo [6.6.1.02,6.010,14] pentadecane scaffold from Cassia buds. Org. Lett. 2019, 21, 549-553. [CrossRef]

119. Chopra, B.; Dhingra, A.K.; Dhar, K.L.; Nepali, K. Emerging role of terpenoids for the treatment of cancer: A review. Mini Rev. Med. Chem. 2021. [CrossRef]

120. Hentschel, V.; Kranl, K.; Hollmann, J.; Lindhauer, M.G.; Bohmand, V.; Bitsch, R. Spectrophotometric determination of yellow pigment content and evaluation of carotenoids by highperformance liquid chromatography in durum wheat grain. J. Agric. Food Chem. 2002, 50, 6663-6668. [CrossRef]

121. Sommer, A.; Davidson, F.R. Assessment and control of vitamin a deficiency: The annecy accords. J. Nutr. 2002, 132, 2845S-2850S. [CrossRef]

122. Orta-Amaro, M. Copal: Microestructura, Composición y Algunas Propiedades Relevantes. Ph.D. Thesis, National Polytechnic Institute of Mexico, Mexico City, Mexico, 2007.

123. Langenheim, J.H. Plant Resins: Chemistry, Evolution, Ecology and Ethnobotany; Timber Press: Portland, OR, USA, 2003; ISBN 978-0881925746.

124. Perveen, K.; Bokhari, N.A.; Siddique, I.; Al-Rashid, S.A.I. Antifungal Activity of Essential Oil of Commiphora molmol Oleo Gum Resin. J. Essent. Oil Bear. Plants 2018, 21, 667-673. [CrossRef]

125. Khaled, M.; Jiang, Z.Z.; Zhang, L.Y. Deoxypodophyllotoxin: A promising therapeutic agent from herbal medicine. J. Ethnopharmacol. 2013, 149, 24-34. [CrossRef] [PubMed]

126. Yang, X.Y.; Zhang, Y.F.; Liu, L.J.; Wang, Y.; Shang, M.Y.; Xu, F.; Liu, G.X.; Cai, S.Q. Lignans and diterpenes isolated from Tirpitzia ovoidea and their biological activities. Chin. J. Nat. Med. 2017, 15, 938-943. [CrossRef]

127. Tsuchiya, H. Anesthetic Agents of Plant Origin: A Review of Phytochemicals with Anesthetic Activity. Molecules 2017, $22,1369$. [CrossRef] [PubMed]

128. Yana, Y.X.; Suna, Y.; Lia, Z.R.; Zhoua, L.; Qiu, M.H. Chemistry and Biological Activities of Buxus Alkaloids. Curr. Bioact. Compd. 2011, 7, 47-64. [CrossRef]

129. Yan, Y.X.; Chen, J.C.; Sun, Y.; Wang, Y.Y.; Su, J.; Li, Y.; Qiu, M.H. Triterpenoid alkaloids from Buxus microphylla. Chem. Biodivers. 2010, 7, 1822-1827. [CrossRef] [PubMed]

130. Afek, U.; Aharoni, N.; Carmeli, S. Increasing celery resistance to pathogens during storage and reducing high-risk psoralen concentration by treatment with GA3. J. Am. Soc. Hort. Sci. 1995, 120, 562-565. [CrossRef]

131. Yasaman, M.; Abbaspour, H.; Peyvandi, M.; Naghavi, M.R. Investigation of gene expression diversity in Hypericum spp. before and after flowering under different nitrogen fertilization levels. Acta Agric. Slov. 2020, 116, 83-92. [CrossRef]

132. Gallego, R.; Bueno, M.; Herrero, M. Sub- and supercritical fluid extraction of bioactive compounds from plants, food-by-products, seaweeds and microalgae-An update. Trends Anal. Chem. 2019, 116, 198-213. [CrossRef]

133. Wang, M.; Wang, J.; Zhou, Y.; Zhang, M.; Xia, Q.; Bi, W.; Chen, D.D.Y. Ecofriendly mechanochemical extraction of bioactive compounds from plants with deep eutectic solvents. ACS Sustain. Chem. Eng. 2017, 5, 6297-6303. [CrossRef]

134. Sati, P.; Dhyani, P.; Bhatt, I.D.; Pandey, A. Ginkgo biloba flavonoid glycosides in antimicrobial perspective with reference to extraction method. J. Trad. Complement. Med. 2017, 9, 15-23. [CrossRef]

135. Lisjak, K.; Lelova, Z.; Žigon, U.; Bolta, Š.V.; Teissedre, P.L.; Vanzo, A. Effect of extraction time on content, composition and sensory perception of proanthocyanidins in wine-like medium and during industrial fermentation of Cabernet Sauvignon. J. Sci. Food Agric. 2020, 100, 1887-1896. [CrossRef]

136. Suh, S.; Kim, Y.E.; Yang, H.J.; Ko, S.; Hong, G.P. Influence of autoclave treatment and enzymatic hydrolysis on the antioxidant activity of Opuntia ficus-indica fruit extract. Food Sci. Biotechnol. 2017, 26, 581-590. [CrossRef]

137. Novaes, F.J.M.; Lima, F.A.; Calado, V.; Marriott, P.J.; de Aquino Neto, F.R.; Rezende, C.M. Isolating valuable coffee diterpenes by using an inexpensive procedure. Ind. Crops Prod. 2020, 152, 112494. [CrossRef]

138. Zhou, L.; Jiang, B.; Zhang, T.; Li, S. Ultrasound-assisted aqueous two-phase extraction of resveratrol from the enzymatic hydrolysates of Polygonum cuspidatum. Food Biosci. 2019, 31, 100442. [CrossRef]

139. Kovacevic, D.B.; Maras, M.; Barba, F.J.; Granato, D.; Roohinejad, S.; Mallikarjunan, K.; Montesano, D.; Lorenzo, J.M.; Putnik, P. Innovative technologies for the recovery of phytochemicals from Stevia rebaudiana Bertoni leaves: A review. Food Chem. 2018, 268, 513-521. [CrossRef] [PubMed]

140. Kovačević, D.B.; Barba, F.J.; Granato, D.; Galanakis, C.M.; Herceg, Z.; Dragović-Uzelac, V.; Putnik, P. Pressurized hot water extraction (PHWE) for the green recovery of bioactive compounds and steviol glycosides from Stevia rebaudiana Bertoni leaves. Food Chem. 2018, 254, 150-157. [CrossRef] [PubMed]

141. Hatami, T.; Johner, J.C.F.; Zabot, G.L.; Meireles, M.A.A. Supercritical fluid extraction assisted by cold pressing from clove buds: Extraction performance, volatile oil composition, and economic evaluation. J. Supercrit. Fluids 2018, 144, 39-47. [CrossRef]

142. Nastić, N.; Švarc-Gajić, J.; Delerue-Matos, C.; Barroso, M.F.; Soares, C.; Moreira, M.M.; Morais, S.; Maskovic, P.; Srcek, V.G.; Slivac, I.; et al. Subcritical water extraction as an environmentally-friendly technique to recover bioactive compounds from traditional Serbian medicinal plants. Ind. Crops Prod. 2018, 111, 579-589. [CrossRef] 
143. El Kantar, S.; Boussetta, N.; Lebovka, N.; Foucart, F.; Rajha, H.N.; Maroun, R.G.; Louka, N.; Vorobiev, E. Pulsed electric field treatment of citrus fruits: Improvement of juice and polyphenols extraction. Innov. Food Sci. Emerg. Technol. 2018, 46, 153-161. [CrossRef]

144. Barba, F.J.; Brianceau, S.; Turk, M.; Boussetta, N.; Vorobiev, N. Effect of Alternative Physical Treatments (Ultrasounds, Pulsed Electric Fields, and High-Voltage Electrical Discharges) on Selective Recovery of Bio-compounds from Fermented Grape Pomace. Food Bioprocess. Technol. 2015, 8, 1139-1148. [CrossRef]

145. Zhou, Y.H.; Vidyarthi, S.K.; Zhong, C.S.; Zheng, Z.A.; An, Y.; Wang, J.; Wei, Q.; Xiao, H.W. Cold plasma enhances drying and color, rehydration ratio and polyphenols of wolfberry via microstructure and ultrastructure alteration. LWT 2020, $134,110173$. [CrossRef]

146. Naviglio, D. Naviglio's principle and presentation of an innovative solid-liquid extraction technology: Extractor Naviglio ${ }^{\circledR}$. Anal. Lett. 2003, 36, 1647-1659. [CrossRef]

147. Rocchetti, G.; Blasi, F.; Montesano, D.; Ghisoni, S.; Marcotullio, M.C.; Sabatini, S.; Cossignani, L.; Lucini, L. Impact of conventional/non-conventional extraction methods on the untargeted phenolic profile of Moringa oleifera leaves. Food Res. Int. 2019, 115, 319-327. [CrossRef] [PubMed]

148. Duan, L.; Zhang, W.H.; Zhang, Z.H.; Liu, E.H.; Guo, L. Evaluation of natural deep eutectic solvents for the extraction of bioactive flavone C-glycosides from Flos Trollii. Microchem. J. 2019, 145, 180-186. [CrossRef]

149. Shikov, A.N.; Kosman, V.M.; Flissyuk, E.V.; Smekhova, I.E.; Elameen, A.; Pozharitskaya, O.N. Natural Deep Eutectic Solvents for the Extraction of Phenyletanes and Phenylpropanoids of Rhodiola rosea L. Molecules 2020, 25, 1826. [CrossRef] [PubMed]

150. Fernández, K.; Vega, M.; Aspé, E. An enzymatic extraction of proanthocyanidins from País grape seeds and skins. Food Chem. 2015, 168, 7-13. [CrossRef]

151. Nadar, S.S.; Rao, P.; Rathod, V.K. Enzyme assisted extraction of biomolecules as an approach to novel extraction technology: A review. Food Res. Int. 2017, 108, 308-330. [CrossRef] 